\title{
2
}

\section{China's Belt and Road Initiative: Contributions to connectivity}

\author{
Pelagia Karpathiotaki, Yunhua Tian, Yanping Zhou \\ and Xiaohao Huang
}

\section{Introduction}

The first signs of China's desire to go abroad in a coordinated manner can be found in the first speech of Xi Jinping on 15 November 2012 in Beijing, when he emerged as general secretary of the Chinese Communist Party and, among others, highlighted the priority of national rejuvenation and China's role in world affairs:

Our responsibility is to unite and lead people of the entire party and of all ethnic groups around the country while accepting the baton of history and continuing to work for realizing the great revival of the Chinese nation in order to let the Chinese nation stand more firmly and powerfully among all nations around the world and make a greater contribution to mankind. (BBC News 2012)

That day marked a turning point, as it changed the way China viewed the rest of the world and upgraded its role as a global player.

About a year later, in September 2013, during a visit to Kazakhstan, President Xi made a speech titled 'Promote People-to-People Friendship and Create a Better Future' and introduced the Silk Road Economic 
Belt (SREB) (an overland route), which, along with the 21st Century Maritime Silk Road (MSR) (a maritime route), announced a month later in Indonesia, came to be collectively known today as the Belt and Road Initiative (BRI). The first geographical presentation of the BRI was made in a map published by Xinhua News Agency on 8 May 2014. According to this map, the SREB would begin in Xi'an, whereas the MSR would start in Quanzhou's harbour in Fujian Province.

The political significance of the BRI initially was demonstrated in the 'Decision of the Central Committee of the Communist Party of China on Some Major Issues Concerning Comprehensively Deepening the Reform', adopted on 12 November 2013, according to which:

We will set up development-oriented financial institutions, accelerate the construction of infrastructure connecting China with neighbouring countries and regions, and work hard to build a Silk Road Economic Belt and a Maritime Silk Road, so as to form a new pattern of all-round opening. (Article 26, Section VII)

The BRI has become so integral to China's foreign policy strategy that it was adopted into the Chinese Communist Party's constitution on 24 October 2017:

The Party shall constantly work to develop good neighbourly relations between China and its surrounding countries and work to strengthen unity and cooperation between China and other developing countries. It shall follow the principle of achieving shared growth through discussion and collaboration, and pursue the Belt and Road Initiative. (CPC 2017)

Since 2013, many official documents and white papers have been published that clarify the principles, priorities and thematic specialisations of the BRI. Undoubtedly, the first official and probably one of the most important documents on the BRI was the 'Vision and Actions on Jointly Building the Silk Road Economic Belt and 21st Century Maritime Silk Road', jointly issued by the National Development and Reform Commission (NDRC), the Ministry of Foreign Affairs and the Ministry of Commerce at the Boao Forum on 28 March 2015. It is an action plan on the principles, framework and cooperation priorities and mechanisms of the BRI. 
According to this document, the BRI is:

- open to all countries, and international and regional organisations for engagement

- advocates peace and cooperation, openness and inclusiveness, mutual learning and mutual benefit

- promotes practical cooperation in all fields, and works to build a community of shared interests, destiny, and responsibility featuring mutual political trust, economic integration and cultural inclusiveness.

In 2016, the State Council published the Thirteenth Five-Year Plan for National Informatisation, devoting a section to the construction of an 'online Silk Road' and encouraging the full participation of Chinese internet companies. In May 2017, speaking at the first BRI forum in Beijing, President Xi reiterated the critical role of the digital Silk Road in the overall initiative. He called for further integration into the BRI of next-generation network technologies-including artificial intelligence, nanotechnology, quantum computing, big data, cloud computing and the concept of smart cities-to enable innovation-driven development (Xinhuanet 2017).

In January 2017, China and the World Health Organization (WHO) agreed to jointly implement a BRI project focused on health. In August that year, China hosted an international conference on health related to the Silk Road. On 16 March 2020, during the COVID-19 pandemic and while Italy was facing perhaps the greatest humanitarian crisis in its modern history, President $\mathrm{Xi}$, during a phone conversation with then Italian Prime Minister Giuseppe Conte, raised the notion of working closer with Italy to build a 'Health Silk Road'.

Today, the BRI's overland route comprises six land corridors:

1. The China-Mongolia-Russia Economic corridor (CMREC).

2. The New Eurasian Land Bridge (NELB).

3. The China-Central Asia-West Asia Economic Corridor (CCWAEC).

4. The China-Indochina Peninsula Economic Corridor (CIPEC).

5. The China-Pakistan Economic Corridor (CPEC).

6. The Bangladesh-China-India-Myanmar Economic Corridor (BCIMEC). 
In addition, the maritime route of the BRI proposes more direct linkage of Chinese ports with emerging countries and economic regions such as the Association of Southeast Asian Nations (ASEAN). According to another official document, the 'Vision for Maritime Cooperation under the BRI', released on 20 June 2017 by the NDRC and the State Oceanic Administration (SOA), the BRI comprises three sea routes, or blue economic passages:

7. The China-Indian Ocean-Africa-Mediterranean Sea Blue Economic Passage, linking the CIPEC, CPEC and CCIMEC.

8. The China-Oceania-South Pacific Blue Economic Passage.

9. The China-Northern Europe Blue Economic Passage, through the Arctic Ocean.

On 28 January 2018, China’s State Council Information Office released a white paper titled 'China's Arctic Policy', detailing the country's plan to develop shipping lanes opened up by climate change.

The original name of the BRI was coined in 2013 by President Xi, who drew inspiration from the concept of the Silk Road, which was established during the Han Dynasty 2,000 years ago and was an ancient network of trade routes that had for centuries connected China to the Mediterranean via Eurasia. The term 'Silk Road' was coined by German geographer Ferdinand von Richthofen in 1877. In China, the ancient trading routes across Eurasia were more prosaically called the northern and southern routes. The reference to the ancient Silk Road was not chosen by chance. It conjures up images of peaceful and diverse exchanges from one prosperous end of the Eurasian continent to the other and is easily identifiable in countries outside China as a shared heritage defying civilisational differences.

Chinese sources never refer to the BRI as the New Silk Road Initiative (NSRI) because this term was first envisioned in 2011 by the United States as a means for Afghanistan to integrate further into the region by resuming traditional trading routes and reconstructing significant infrastructure links broken by decades of conflict. The NSRI shares a focus on energy and transportation infrastructure with China's SREB.

In the 'Vision and Actions' document, the BRI is described as 倡议 ('a call for action'), translated into English as 'initiative'. In August 2015, China's NDRC, together with the Ministry of Foreign Affairs and Ministry of Commerce, clarified that the BRI is the official English translation and words such as 'strategy', 'program', 'agenda' and 'project' are inaccurate 
(Xie 2015). According to the official documents, the BRI is a unilateral concept that requires willing cooperation from others who also have a stake in the provision of public goods, which is why Chinese officials will not use the term 'strategy', which requires close association or alliances among those who share its specific goals. Because the initiative relies on voluntary participation, it faces a collective action problem.

The BRI is not just a development plan; it is also an important element of Chinese foreign policy in the twenty-first century, and therefore the definition of what constitutes a BRI project is broad. For the purposes of this chapter, BRI projects are any that originated in China (that have direct Chinese participation at a consultant, owner, contractor and financer level) and are focused on Asia, Europe and Africa, but open to all partners and fulfil the scope of the two Chinese policy documents that outline the BRI: the 'Vision and Actions on Jointly Building the Silk Road Economic Belt and 21st Century Maritime Silk Road' and the 'Vision for Maritime Cooperation under the Belt and Road Initiative'. In 2019, the NDRC compiled an official list of participating BRI nations and approved projects. Many of the BRI-branded projects began before 2013 but gained momentum under the initiative.

In this chapter, we focus on the contributions of the BRI to connectivity, and its consequences, but first, we examine some of its philosophical and geopolitical features, including its governance. These are the topics of the following two sections. We then identify the BRI's contributions to connectivity. We examine the economic effects of connectivity on trade, foreign investment and global value chains. Subsequently, we examine some risks in the BRI, including political and legal, debt sustainability questions, governance risks and those associated with the environment. The final section of the chapter provides a conclusion.

\section{BRI foundations}

\section{Philosophy}

The BRI is a unique megaproject in global economic history, which is in line with President Xi's 'Thoughts' on China as a global power and globalisation in the twenty-first century, and which contributes to his mission of national rejuvenation. At its core, the initiative incorporates elements of Chinese and Western philosophy. 
In contrast with Western philosophy, the BRI is not a project 'based on models', which means it does not have a clearly defined framework, clearly measurable goals or defined action steps or a timetable, but will gradually evolve and adapt to the dynamics of the international environment. The BRI generates strategic flexibility, seeks relative advantage for China and preaches avoidance of direct conflict. According to Chinese philosophy, a Chinese general does not set goals or make plans; he tries to detect and exploit the internal dynamics of the 'environment' and adapts his decisions to the natural course of things, to make the conditions work in his favour.

Another element of Chinese philosophy that also characterises the BRI is 'transformation'-mainly as an ideological concept. According to Engels and Marx, only in the final analysis is the economy the driving force of history, but people are becoming aware of the conflicts that are taking place in the economic world, in the ideological field. 'Transformation' is a process that causes gradual changes that often are not visible in the short term, reducing the chance of friction, in contrast with the term 'action' (as in Western philosophy), in which friction is usually inevitable. Through the BRI, China seeks to 'transform' the international environment and promote an alternative model of globalisation and world order adapted to the twenty-first century with a moral advantage to create a fairer world based on globally accepted values (not Western or Eastern) and without any discrimination regarding different political or social systems (Karpathiotaki 2016).

On the other hand, the official geographical presentation of the BRI and its basic principles incorporate elements of Western philosophy and culture. The BRI's 'roads', 'corridors' and 'passages' give shape to the project, creating geometric 'ideal models', which in fact are not absolutely and immediately applicable but they contribute to a better understanding of the project by the Western world. In addition, the principles and values that officially are promoted by the BRI are in line with the principles of the UN Charter, and especially Article 26 of the Charter of Economic Rights and Duties of States adopted by the UN General Assembly in 1974:

All States have the duty to coexist in tolerance and live together in peace, irrespective of differences in political, economic, social and cultural systems, and to facilitate trade between States having different economic and social systems. International trade should be conducted without prejudice to generalized non-discriminatory 
and non-reciprocal preferences in favour of developing countries, on the basis of mutual advantage, equitable benefits and the exchange of most-favoured-nation treatment. (UN 1974)

The BRI is China's attempt to balance the Western-centric perception of the world and propose a new world order that resembles the one determined in 1648 by the Peace of Westphalia treaties. China, through the BRI, seeks to redefine the role of the 'state' in the twenty-first century as the basic political unit of the international system, which can interact with other states in the global market but at the same time maintains control of its economic future, its political system and its foreign policy. This is in contrast to the perception of the 'flat world', without 'borders', which in some degree described globalisation until recently.

The success of the BRI is not easily or immediately measurable but it will be judged largely at the ideological level and, in future, it could be measured by the impact it has on the global community and the acceptance of the BRI's values.

\section{Geopolitics}

China is the largest nation in Eurasia, with an extensive coastline stretching from the tropical zone to the temperate zone. It has one of the most advantageous geographical positions on the planet, while from a geopolitical point of view, it faces challenges through its proximity to other potential world powers (Russia, India, Japan). In this environment, China's strategic decision to 'go out' by land and sea through the BRI could be seen as an expected and realistic political decision, with its main goals, on the one hand, to achieve its key national interests of economic survival and growth and, on the other, to increase its political capital at the international level to settle key issues of its national security. The BRI does not take a missionary approach to international relations, as was the case with the United States after World War II, because China does not seem to propagate any particular ideology or system of governance.

The BRI is an effort to create a network of infrastructure on the southern Eurasian coast ('Rimland') and in Central Asia ('Heartland'), but also in the Arctic north, with final destinations in Europe that could lead to the unification of Eurasia and provide autonomy from the oceanic communications network dominated by the United States. 
This infrastructure could shape a new anthropogeographic reality in Eurasia that could affect the international system and have extremely important geopolitical implications for the world (Costas 2019).

The BRI could be seen as China's 'anti-containment' strategy because it contributes to the 'unification' of Eurasia-an attempt to counter the United States' 'containment' strategy that traditionally seeks the 'division' of Eurasia and the prevention of the emergence of a dominant power in the region. The United States' containment strategy incorporates theoretical elements of different geopolitical theories (Mackinder, Spykman and Mahan), emphasises control of Rimland (Asia Minor, Arabia, Iran, Afghanistan, Southeast Asia, China, Korea and eastern Siberia excluding Russia), and combines Mackinder-Spykman's theory with Mahan's argument, which considered naval power and control of the ocean as the key elements for world domination.

The melting of the Arctic ice sheet 'liberates' Russia from the north, with Rimland no longer a semicircle formed by the inaccessibility of the Arctic, and now more of a ring. The melting of the Arctic ice not only adds more sea routes to the existing maritime transportation network but also contributes to the 'unification' of the Eurasian maritime region into a single and indivisible web of maritime routes that allow the Eurasian east to communicate with the west without crossing the open ocean dominated by the United States. The MSR and the Polar Silk Road (PSR) are key elements of China's strategy and contribute to the shaping of a single maritime transportation web around the Eurasian continent, which geopolitically is much more important than the simple sum of its various sea routes (Costas 2019).

In conclusion, the BRI is a key element of a new geopolitical mechanism that, seeking to protect China's national and security interests, incorporates historical experience (the Cold War), is a response to US efforts to contain China's emergence and contributes to the transfer of the balance of power from the Western hemisphere to the Eastern, which could facilitate the emergence of a new bipolar global system to succeed the current unstable multipolar one. Even if the international system does not become bipolar in the near future, a multipolar system based on a more equal balance of power could create greater stability in the international system than what we are experiencing today. 


\section{Development}

China's BRI is the largest such initiative in global history. Investing in infrastructure is a crucial aspect of a successful growth strategy. Woetzel et al. (2017) find that in all countries there is a significant gap between what they are spending and their infrastructure requirements if they are to continue to grow well until 2035. The BRI initiative is generally popular in the developing world, where almost all countries face infrastructure deficiencies and are not willing to attract private investment, which generally requires a very high rate of return, making it expensive. Therefore, developing countries that want to establish infrastructure quickly often have little alternative than to participate in the BRI.

China lends money to developing countries to construct infrastructure for transport, power and water supply and other sectors. In his opening remarks at the Belt and Road Forum in Beijing in May 2017, President $\mathrm{Xi}$ noted: 'Infrastructure connectivity is the foundation of development through cooperation ... We should improve transregional logistics networks and promote connectivity of policies, rules and standards so as to provide institutional safeguards for enhancing connectivity' (Xinhuanet 2017).

The World Bank and other development banks were originally set up for this core function, but now only about 30 per cent of World Bank lending is for infrastructure and its procedures are extraordinarily bureaucratic and time-consuming (Jones 2019). On the other hand, China is offering to finance infrastructure at what could be called commercial terms. Most of its loans are in dollars on commercial terms that are more generous than developing countries can get from private investors, but much more costly than funds from Western donors or the concessional windows of the multilateral development banks (Dollar 2020). In addition, many BRI projects would be unbankable by Western standards. Even so, they can still be important to the countries involved and they 'make sense' to China.

To illustrate, ASEAN countries traditionally could rely on Western support-through bilateral financing and the multilateral development banks - to finance some of their infrastructure investment. However, that is no longer the case. Japan is the only remaining significant financier of infrastructure. During 2015-17, Japan committed US\$13 billion to transport and energy infrastructure in ASEAN countries. No other Western 
donor reached $\$ 1$ billion per year. The total from the six major Western sources-Australia, Japan, the Asian Development Bank (ADB), World Bank, United States and South Korea-amounted to about 2 per cent of the infrastructure financing needs of the ASEAN countries. There are two main reasons for this: first, the overall amount of Western aid is not keeping up with demand and, second, the donors are generally turning away from infrastructure. Another aspect of declining Western support is the ideological view that infrastructure can be left to private investment, which has proved hard to achieve.

\section{BRI governance}

The BRI has typically been described as a cooperative arrangement among likeminded states interested in advancing infrastructure and connectivity projects around the world. The initiative is not yet a formal institutionalised body and is still highly centralised and coordinated from the top by the Chinese political leadership. As the breadth and depth of the BRI have grown in terms of the projects undertaken, the actors involved and the objectives being pursued, the need for a more formalised institutional architecture has become clear.

\section{Institutional evolution}

On 4 November 2014, the eighth meeting of the Central Leading Group for Financial and Economic Affairs, chaired by President Xi, focused on the BRI. On 9-11 December 2014, the BRI was identified at the Central Economic Work Conference as a key strategy for 2015 for the promotion of regional economic development. At the end of March 2015, the Chinese Government issued its 'Vision and Actions' document defining the BRI's guiding principles, routes and cooperation priorities and identifying the NDRC as the lead organisation for coordinating BRI efforts, with some shared responsibility from the ministries of commerce and foreign affairs. At the same time, two task forces were established under the State Council's guidance to supervise all BRI-related activities: the Leading Small Group on Advancing the Construction of the Belt and Road, and the Office of the Leading Small Group on Advancing the Construction of the Belt and Road, located within the NDRC, which manages the dayto-day central oversight and coordination work with relevant ministries 
and entities. In addition, in 2017, the Belt and Road Promotion Centre within the NDRC was created. Moreover, nearly 32 Chinese provinces are also participating.

At the top of the chain, President $\mathrm{Xi}$ gives guidance during regular study sessions specifically dedicated to the BRI. Following the Thirteenth National People's Congress in March 2018, Vice-Premier and Politburo Standing Committee member Han Zheng became chairman of the Leading Small Group, while State Counsellor and former minister of foreign affairs Yang Jiechi, Vice-Premier Hu Chunhua, Secretary-General of the State Council Xiao Jie and NDRC Director He Lifeng assumed responsibility as vice-chairmen.

BRI leading small groups have also been created in relevant Chinese ministries and in each province. Similar to the central one, ministerial and provincial groups meet on a regular basis and include representatives from a variety of relevant government entities whose responsibilities pertain to the advancement of the BRI. Since 2013, several white papers have been released to inform global audiences of the BRI's new priorities.

China has vowed to provide financial support for the BRI. In its initial stages, the Chinese Government extended the scope of its financial backing to US $\$ 90$ billion for the Silk Road Fund (SRF), which was established in 2014 to foster development along the BRI route. Its major stakeholders are the State Administration of Foreign Exchange, the Export-Import Bank of China (Exim Bank), China Investment Corporation and China Development Bank. Moreover, China has built very large banking institutions to support its outward investments and its credit, lending and aid activities, such as the China Development Bank (CDB) and the Exim Bank.

\section{BRI takes a more multilateral approach}

To date, China has organised two Belt and Road Forums (BRFs) for International Cooperation in Beijing, in 2017 and 2019, with the participation of state leaders from around the world. The purpose of the BRF is to build a more open and efficient international cooperation platform, a closer, stronger partnership network and to push for a more just, reasonable and balanced international governance system. Key terms supporting multilateralism—such as 'inclusive', 'voluntary participation' and 'being open to all and respectful of national and international 
commitments' - have been prominent in the forum's rhetoric. President $\mathrm{Xi}$ called for the BRF to become a regular event, suggesting it would be used to implement a multilateral institutional architecture for the BRI.

In addition to the BRF, China has initiated two international developmentoriented banks, the Asian Infrastructure Investment Bank (AIIB) and the New Development Bank (NDB). The AIIB began operations in January 2016 and has evolved into a high-profile multilateral institution that now has 102 approved members worldwide, while the NDB was established in 2014 and remains largely restricted to the five BRICS countries (Brazil, Russia, India, China and South Africa).

Another aspect of the BRI related to global governance is collaboration with multilateral development banks (MDBs) - in particular, the World Bank Group, the European Bank for Reconstruction and Development, the ADB, the AIIB, the NDB and the European Investment Bank. These six MDBs signed a joint memorandum of understanding with China on 14 May 2017 to support the BRI. In terms of overall finances and institutions, however, the MDBs are only one piece of a larger picture.

In recent years and especially since the first BRF, Beijing has taken a range of steps to exert more control over the BRI, including a more muted publicity drive, clearer rules for state-owned enterprises, restricting the use of the BRI brand and building overseas auditing and anticorruption mechanisms. It is also stepping up efforts to get developed nations to join in to spread the risk of building projects in poorer nations and to counter allegations the BRI is an attempt to build China's political influence. However, to fully engage with other stakeholders, China would have to invent a bureaucratic framework with reasonable consistency, setting up clear criteria for selecting potential projects that are credit-worthy. This consistency would have to be spelt out clearly, and practised diligently, to reassure international partners.

In May 2017, during the first BRF for International Cooperation, the BRF Advisory Council was created to give multilateral intellectual support to the forum. The council is an international policy advisory body with 11 members from international organisations, research and politics. Two members are from China and the remainder are from Asia, Europe and Africa. The council is led by Shamshar Akhtar, former executive secretary of the UN Economic and Social Commission for Asia 
and the Pacific, and Justin Yifu Lin, former senior vice-president of the World Bank and Honorary Dean of the National School of Development at Peking University.

The BRF and its advisory council could emerge as the major multilateral platform for BRI cooperation. They may also benefit from the models of some existing multilateral platforms on how to institute an architecture of supporting mechanisms. The principles of extensive consultation, joint efforts and shared benefits call intrinsically for a multilateral approach to working together. Becoming more multilateral could also broaden the support base of BRI cooperation and enhance the sense of ownership of all partners.

Indicative of this orientation are the findings and recommendations of the first report issued by the BRF Advisory Council. It proposed to promote an open world economy by fostering a global, broad-based partnership built on connectivity, to focus on building high-quality BRI cooperation by galvanising a shared commitment to multilateralism, to build a 'clean Silk Road' with 'zero tolerance for corruption' and to use green finance to accelerate achieving the ambitions of the BRI. According to the report, the development of cooperative financing and sectoral multilateral mechanisms would also be essential for sustaining further development of cooperation in the long term.

The BRF Advisory Council has also suggested that BRI cooperation stay committed to upholding multilateralism, safeguarding the rules-based multilateral trading system centred on the World Trade Organization (WTO), promoting free and open trade and investment and opposing all forms of protectionism. However, in this regard, greater synergy needs to be tapped between the BRI and various national, regional and global development strategies, including, among others, the UN 2030 Agenda for Sustainable Development (which aims to improve global development along 17 Sustainable Development Goals), the African Union's Agenda 2063, the development plan of the Eurasian Economic Union, the Master Plan on ASEAN Connectivity, the Asia Pacific Economic Cooperation (APEC) Connectivity Blueprint, the Community of Latin American and Caribbean States (CELAC) and the EU Strategy on Connecting Europe and Asia. 
The move to create a multilateral architecture for the BRI is inevitable. To date, most formal arrangements exist in the form of bilateral treaties or contracts on specific projects. Since its 2013 launch, the BRI has not been described as a formal organisational setup; rather, the BRI has been used as a descriptive label for a range of projects being undertaken around the world that involve China in some way.

The advisory council's report directly addressed the issue of enhancing the BRI's institutional architecture. It suggested the BRF become formalised and meet every two to three years to discuss and set the broad parameters of the BRI. From this, there can also be 'satellite events' on a regional or sectoral basis to examine particular issues. The BRF Advisory Council further recommended expanding and leveraging diversified sources of finance for BRI projects-in particular, to fill the funding gap for sustainable infrastructure.

Formalising the BRI's activities through a multilateral architecture will also bring more effectiveness to the connectivity and infrastructure projects through more organised planning that in turn increases the effectiveness of the projects. And, as the advisory council explains, 'going more multilateral could broaden the supporter base of the Belt and Road cooperation and enhance the sense of ownership of all partners' (Yang 2019). The advisory council's suggestions must be acted on to transform the BRI into a formal international institution.

\section{The BRI's impacts on connectivity}

In this section, we review the consequences of the BRI for both transport and digital connectivity. We then discuss the importance of policy coordination across economies to capture these benefits.

\section{Infrastructure connectivity}

\section{Transport connectivity}

BRI-related transport infrastructure projects—such as railways, highways and ports—will build on existing transportation networks, creating new links and making the connectivity of networks denser. Reed and Trubetskoy (2019) compiled the first geocoded database of BRI transport 
infrastructure projects in Eurasia (see Figure 2.1). ${ }^{1}$ The status of these projects differs widely: some are already operational, such as Highway AH-3 and Highway AH-4 connecting Russia, Mongolia and China; other projects are under construction, like the Juba-Mombasa Railway connecting Kenya and South Sudan; still others are uncertain, such as the Dushanbe-Afghanistan rail upgrade in Tajikistan. In Figure 2.1, the improvement in railway construction is remarkable. For example, while in 2011 there were only 17 trains travelling between Europe and China, carrying goods worth just US\$600 million, by 2018 , there were more than 6,000 train trips between Europe and China carrying goods worth US $\$ 16$ billion (see Figure 2.2). The China-Europe Railway Express connects 108 cities in 16 countries across Eurasia, with the main destinations in Germany, Russia, Kazakhstan, Tajikistan, Poland, Belarus, Netherlands and Uzbekistan.

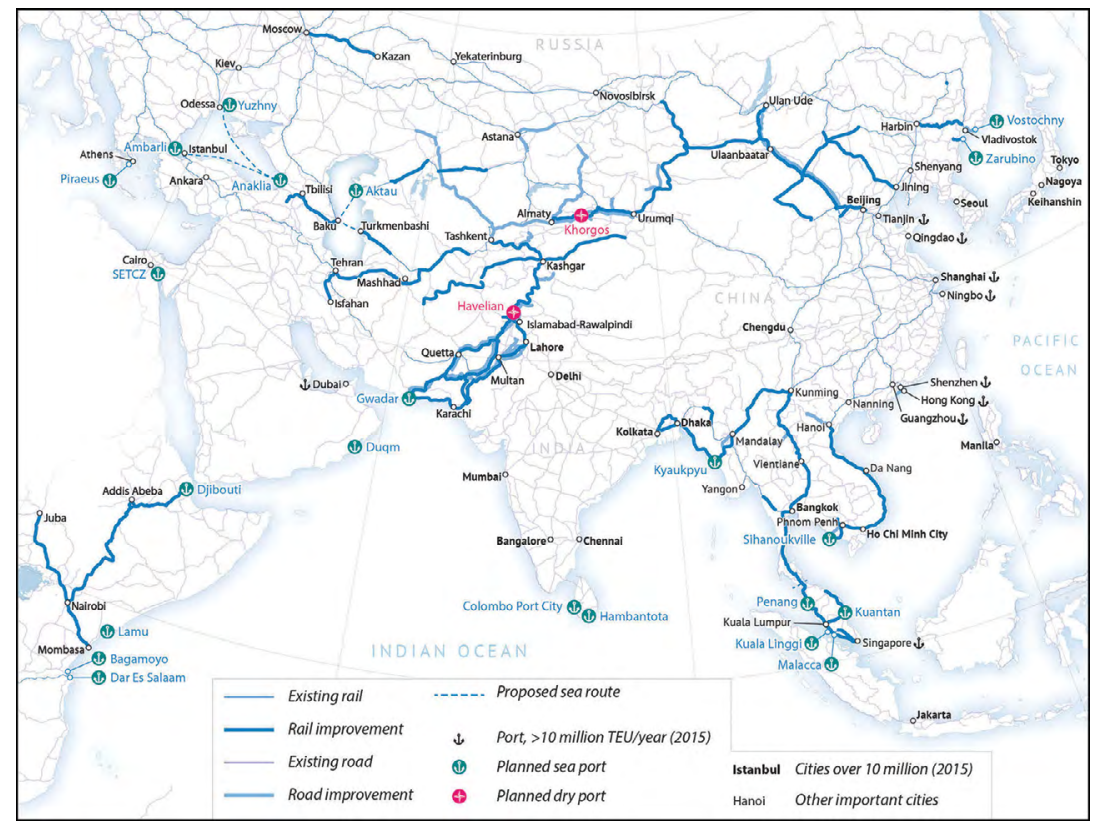

Figure 2.1 BRI-related transport projects by $\mathbf{2 0 1 8}$

TEU = 20-foot equivalent unit

Sources: Reed and Trubetskoy (2019); World Bank (2019).

1 The full list of BRI-related transport projects is provided in Appendix A of Reed and Trubetskoy (2019). It is worth noting that there is no official list and no uniform definition of BRI-related transport projects. 


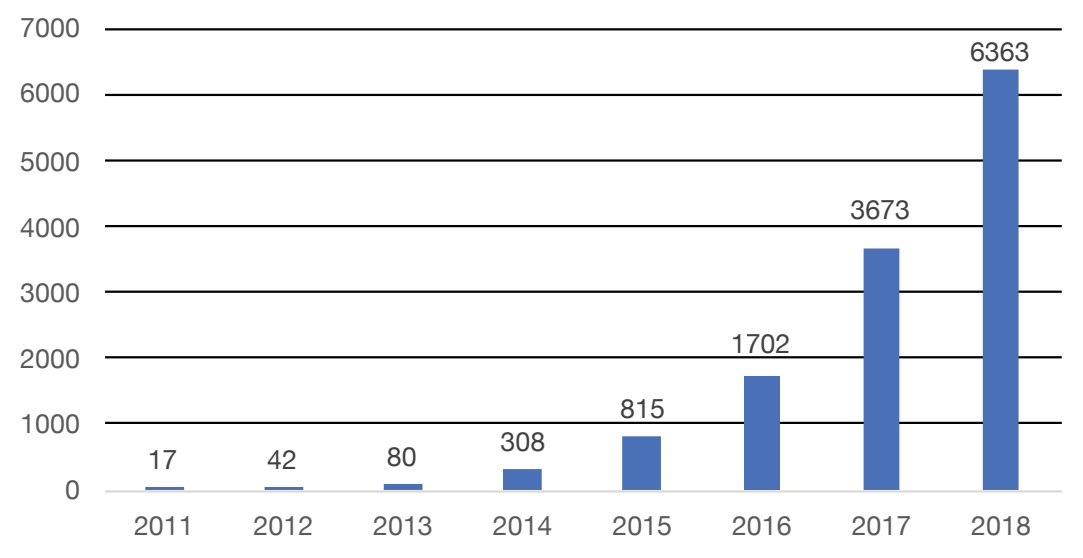

Figure 2.2 Number of China-Europe Railway Express trains, 2011-18

Source: Silk Road Guoxin Big Data Technology Co. Ltd (n.d.).

Based on the list of BRI-related transport projects compiled by Reed and Trubetskoy (2019), de Soyres et al. (2018) obtained information on rail and maritime infrastructure linked to the BRI, allowing a comparison of the pre-BRI and post-BRI scenarios. ${ }^{2}$ They exploit geographic information system (GIS) analysis to calculate the reduction in shipping times between cities. ${ }^{3}$ As a starting point, the transportation network in 2013 was used to estimate the pre-BRI shipping time. The post-BRI travel time is computed in accordance with the 'improved scenario', including all planned BRI-related rail and maritime projects by 2018 .

Before the implementation of the BRI, shipping between some BRI locations was slow as there was little access to quality transport infrastructure and services (see Table 2.1). For instance, the average shipping time within East Asia and the Pacific was longer than within other regions, taking 19.6 days. It takes, on average, 26.8 days to ship goods between East Asia and the Pacific and Central and Eastern Europe, and the average shipping time between East Asia and the Pacific and Central and Western Asia is also long, at 22.5 days.

2 The majority of BRI-related transport projects comprise rail and maritime infrastructure. Note that there is a slight difference between the list in de Soyres et al. (2018: Annex 2) and that in Reed and Trubetskoy (2019).

3 The global database in de Soyres et al. (2018) includes 1,000 cities in 191 countries. 
Table 2.1 Average pre-BRI shipping time within and between regions, 2013

\begin{tabular}{|c|c|c|c|c|c|c|}
\hline $\begin{array}{l}\text { Average } \\
\text { shipping time } \\
\text { (days) }\end{array}$ & $\begin{array}{l}\text { Central } \\
\text { and } \\
\text { Eastern } \\
\text { Europe }\end{array}$ & $\begin{array}{c}\text { Central } \\
\text { and } \\
\text { Western } \\
\text { Asia }\end{array}$ & $\begin{array}{c}\text { East Asia } \\
\text { and the } \\
\text { Pacific }\end{array}$ & $\begin{array}{c}\text { Middle East } \\
\text { and North } \\
\text { Africa }\end{array}$ & $\begin{array}{l}\text { South } \\
\text { Asia }\end{array}$ & $\begin{array}{c}\text { Sub- } \\
\text { Saharan } \\
\text { Africa }\end{array}$ \\
\hline $\begin{array}{l}\text { Central and } \\
\text { Eastern Europe }\end{array}$ & 3.3 & & & & & \\
\hline $\begin{array}{l}\text { Central and } \\
\text { Western Asia }\end{array}$ & 13.4 & 13.0 & & & & \\
\hline $\begin{array}{l}\text { East Asia and } \\
\text { the Pacific }\end{array}$ & 26.8 & 22.5 & 7.1 & & & \\
\hline $\begin{array}{l}\text { Middle East and } \\
\text { North Africa }\end{array}$ & 12.8 & 15.4 & 20.4 & 9.0 & & \\
\hline South Asia & 22.4 & 20.3 & 15.5 & 15.2 & 11.8 & \\
\hline $\begin{array}{l}\text { Sub-Saharan } \\
\text { Africa }\end{array}$ & 19.8 & 23.2 & 20.6 & 14.4 & 17.6 & 4.0 \\
\hline Regional & 13.9 & 16.6 & 19.6 & 14.0 & 17.8 & 18.5 \\
\hline
\end{tabular}

Note: Averaged over all country pairs in each regional pair.

Sources: de Soyres et al. (2018); World Bank (2019).

The implementation of BRI-related transport projects can reduce shipping times for the BRI corridor economies (see Figures 2.3 and 2.4). The findings of de Soyres et al. (2018) show that average shipping time between the BRI economies can decrease by 1.7 per cent (for the lower bound) and 3.2 per cent (for the upper bound). ${ }^{4}$ In particular, the decline in travel time is larger along the BRI economic corridors. The smallest improvement in shipping time is for the China-Mongolia-Russia Economic Corridor, for which the reduction in shipping time ranges between 3.6 per cent and 3.8 per cent on average. The largest improvement is for the China-Central Asia-West Asia Economic Corridor, which will experience a simple average decrease in travel time ranging between 10.3 per cent and 11.9 per cent.

4 In the lower-bound scenario, there is no mode switching between the pre-BRI and the post-BRI shipping routes; in the upper-bound scenario, mode switching is allowed, so that routes can be moved from maritime lanes to railway lines for larger gains in shipping times. 


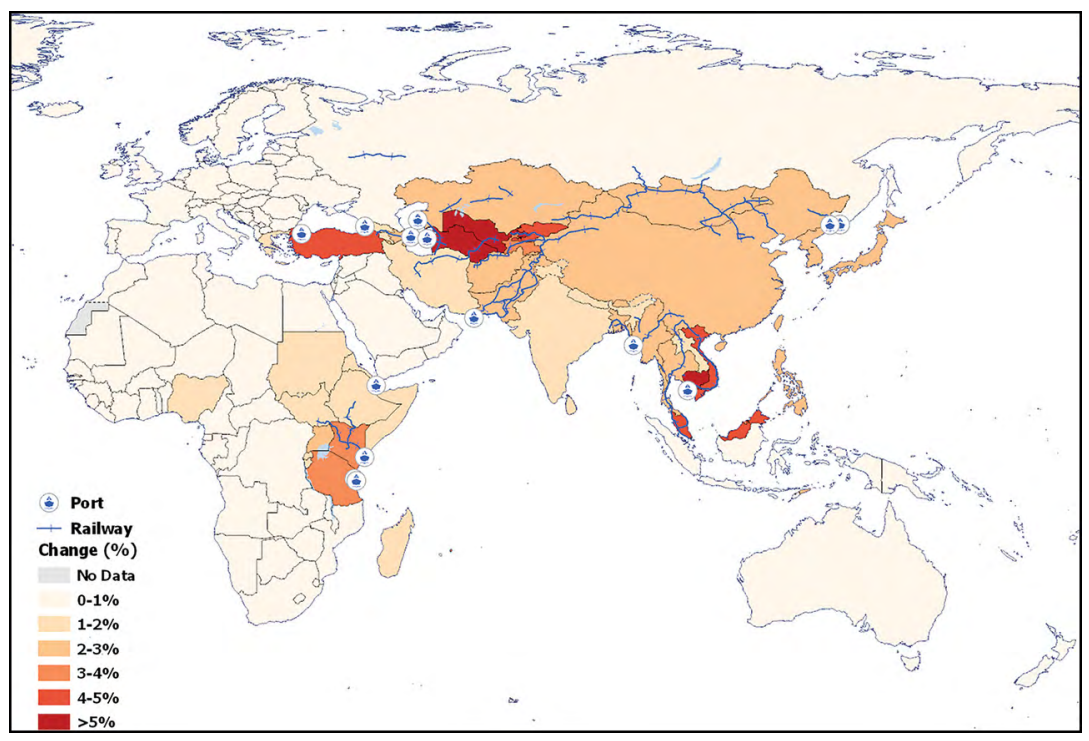

Figure 2.3 Average decline in shipping time by economy: Lower bound

Note: For each economy, the aggregate proportional reduction is calculated as the average proportional shipping time reduction with all other economies in the world.

Source: de Soyres et al. (2018).

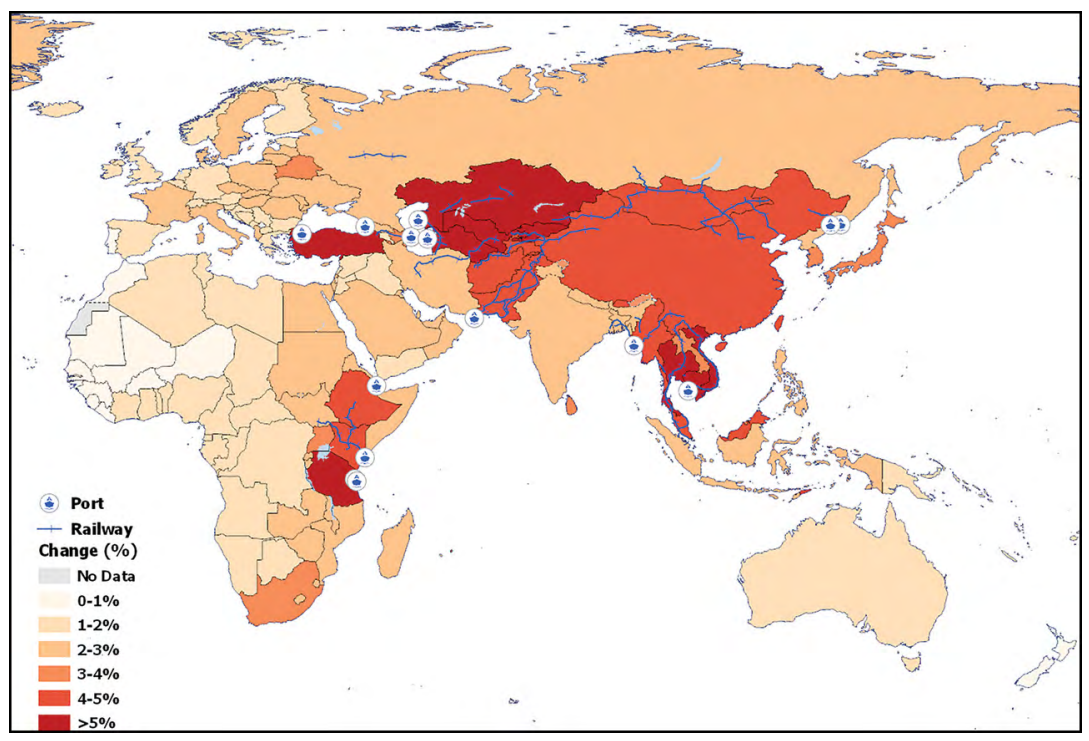

Figure 2.4 Average decline in shipping time by economy: Upper bound

Note: For each economy, the aggregate proportional reduction is calculated as the average proportional shipping time reduction with all other economies in the world.

Source: de Soyres et al. (2018). 
Interestingly, the BRI can induce a positive spillover effect on shipping times for the non-BRI economies, which will also benefit from the improved transportation network when their transport routes pass through the new or upgraded ports or railways. As an example, the construction of Tanzania's Bagamoyo Port is anticipated to benefit not only Tanzania but also surrounding countries. Consequently, when all BRI-related transport projects are implemented, the proportional decrease in travel time from Rwanda to Australia is predicted to be 0.5 per cent. Likewise, the improvement for Djibouti's port will see a reduction of 1.2 per cent in the shipping time between Ethiopia and Australia. In general, shipping times across all country pairs in the world can come down, on average, by 1.2 per cent (for the lower bound) and 2.5 per cent (for the upper bound).

\section{Digital connectivity}

The level of digital connectivity within and between the BRI economies varies widely. The World Bank (2016b) suggests the digital gap within economies can be as large as that between economies. Many people remain untouched by the modern digital revolution. As shown in Figure 2.5a, apart from Singapore, Malaysia, Kazakhstan and economies in the Arabian Peninsula, the proportion of the population using the internet was less than 55 per cent in most Asian economies in 2018, even in China, which had the largest number of internet users. Mobile broadband networks provide a significant channel for digital connectivity, but there are also two extremes to the coverage of fourth-generation (4G) mobile signals among the BRI economies. As shown in Figure 2.5b, $4 \mathrm{G}$ coverage is high in China, Thailand, Eastern Europe and the Arabian Peninsula, but low in the rest of Asia, particularly the landlocked countries.

Efforts are being made to address the digital divide among the BRI economies. According to the China Academy of Information and Communication Technology, China is considering establishing several cross-border overland fibre-optic cable systems and supplying international internet transmission services. Therefore, countries bordering China will have greater access to global submarine cables. So far, remarkable progress has been made in the construction of China-Kyrgyzstan, ChinaMyanmar, China-Pakistan and China-Russia cross-border fibre-optic cables, which will effectively facilitate communication connectivity within the BRI region. In addition, the China-Nepal cross-border fibre-optic cable, which launched in 2018, provides China and East Asian countries with the shortest internet path to Africa and the Middle East. 


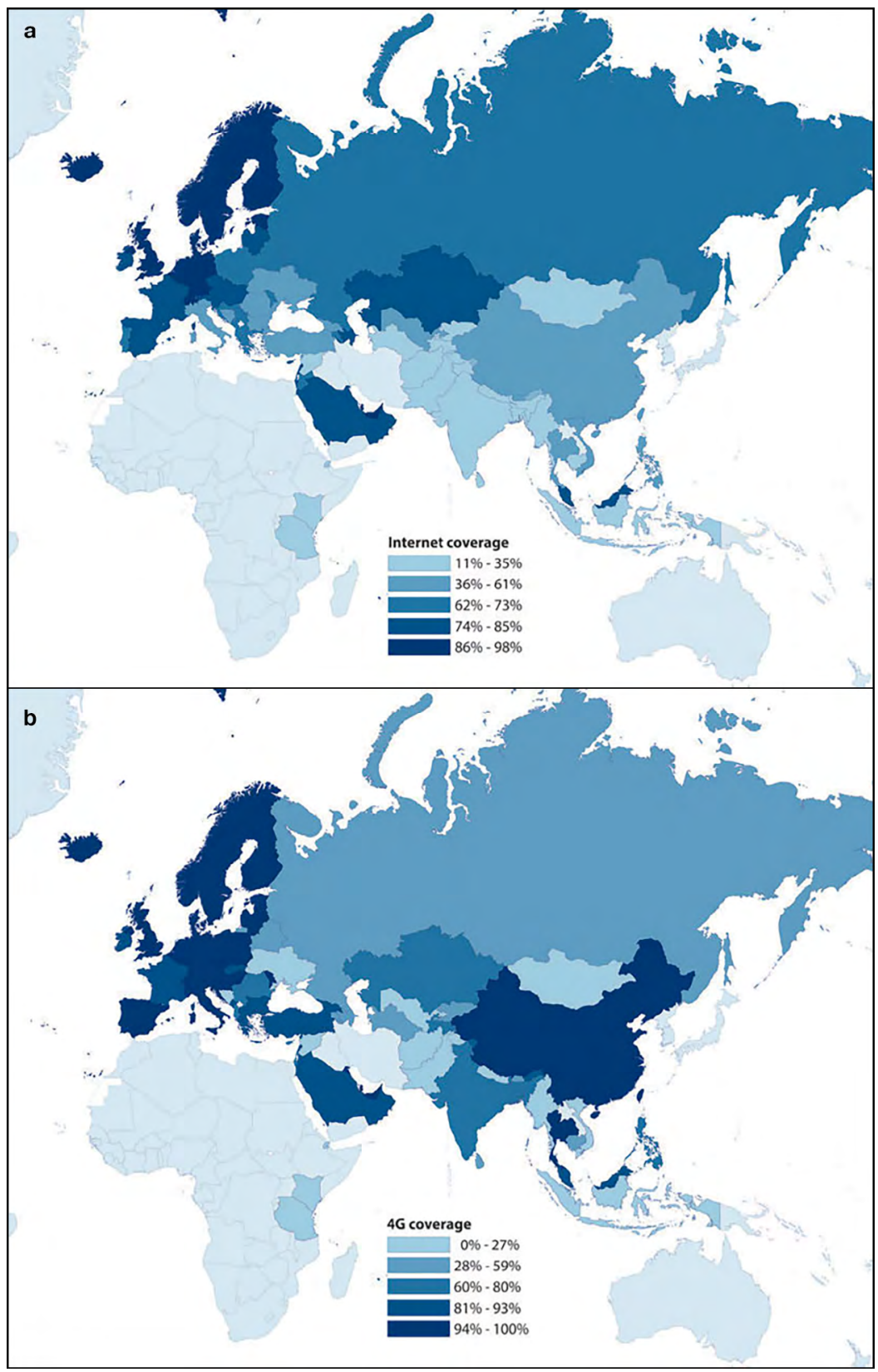

Figure 2.5 Internet users and access to mobile broadband, 2018

a. Internet users (percentage of population) b. $4 \mathrm{G}$ coverage (percentage of population) Note: Western European economies are included as comparators since most BRI-related infrastructure projects are in Eurasia, and a network is only as good as its weakest link. Source: World Bank (2019). 


\section{Policy coordination}

Policy coordination has played a significant role in shortening shipping times - for instance, by reducing border delays and the frequency of cargo transhipment. As an example, although there are roads linking the two non-bordering countries China and Uzbekistan, vehicles from one country were not allowed to enter the other for a long time, so their goods needed to transit through Kyrgyzstan for eight to 10 days. In the wake of the implementation of the 'China-Uzbekistan Intergovernmental Agreement on International Road Transport', the transit period between the two countries has been reduced to two days, and the cost of freight per tonne has been cut by US $\$ 300-500$ (Wu 2018). More and more countries and international organisations have signed intergovernmental BRI cooperation agreements over the years. By the end of January 2020, the Chinese Government had signed 200 cooperation agreements with 138 countries and 30 international organisations. In addition, the BRI has expanded from Eurasia to Africa, Latin America and the South Pacific.

Great importance is attached to the continued integration of the various development strategies, plans, platforms and projects among the BRI economies, achieving complementary advantages and producing effects according to the theory that 'one plus one is greater than two'. So far, the BRI has been dovetailed with Kazakhstan's Bright Road Initiative, Vietnam's Two Corridors and One Economic Circle Plan, Indonesia's Global Maritime Fulcrum Doctrine, Poland's Amber Road Framework, Mongolia's Development Road Program, Saudi Vision 2030 and so on, effectively promoting common prosperity and development.

There are other examples of efforts on policy coordination. First, the Digital Silk Road has been an important part of the BRI. In December 2017, China, Egypt, Laos, Saudi Arabia, Serbia, Thailand, Turkey and the United Arab Emirates jointly launched the Belt and Road Digital Economy International Cooperation Initiative. Sixteen countries have signed a memorandum of understanding with China for the construction of the Digital Silk Road. Second, China published the 'Action Plan on Belt and Road Standard Connectivity (2018-2020)' in December 2017, under which it has signed 85 standardisation cooperation agreements with 49 economies. Third, the BRI's long-term tax cooperation mechanism is maturing. In May 2018, China coorganised the Belt and Road Initiative Tax Cooperation Conference (BRITCC) and issued the 'Astana Proposal 
by BRITCC Participating Jurisdictions for Enhancing Cooperation in Tax Matters', expanding the tax cooperation network to 111 countries and regions. Fourth, in terms of legal operations, China published the 'Statement of the Co-Chairs of the Forum on the Belt and Road Legal Cooperation' in July 2018. Moreover, China has carried out cooperation on intellectual property, issuing the 'Joint Statement on Pragmatic Cooperation in the Field of Intellectual Property Among Countries Along the Belt and Road' with 49 BRI economies in August 2018.

\section{Economic effects of BRI connectivity}

Better infrastructure connectivity and greater policy coordination under the BRI framework can inject strong impetus into the economies of the BRI countries and regions, making the trade network between them more intensive, leading to more foreign direct investment (FDI) flows and improving their positions in global value chains (GVCs).

\section{Impacts on trade}

\section{Trade costs}

Declines in shipping times can be transformed into decreases in trade costs by estimating the 'value of time' by sector (Hummels and Schaur 2013). De Soyres et al. (2018) investigated the BRI's effect on trade costs based on their research on shipping time reductions mentioned above (see Figures 2.6 and 2.7). Their findings show that implementing all BRI-related transport projects will result in a reduction of average trade costs for the BRI economies ranging between 1.5 per cent and 2.8 per cent, and for the world ranging between 1.1 per cent and 2.2 per cent. Similar to the changes in shipping times, trade costs will decrease along the BRI economic corridors, ranging from 2.4 per cent for the China-MongoliaRussia Economic Corridor to 10.2 per cent for the China-Central AsiaWest Asia Economic Corridor in the upper-bound scenario. 


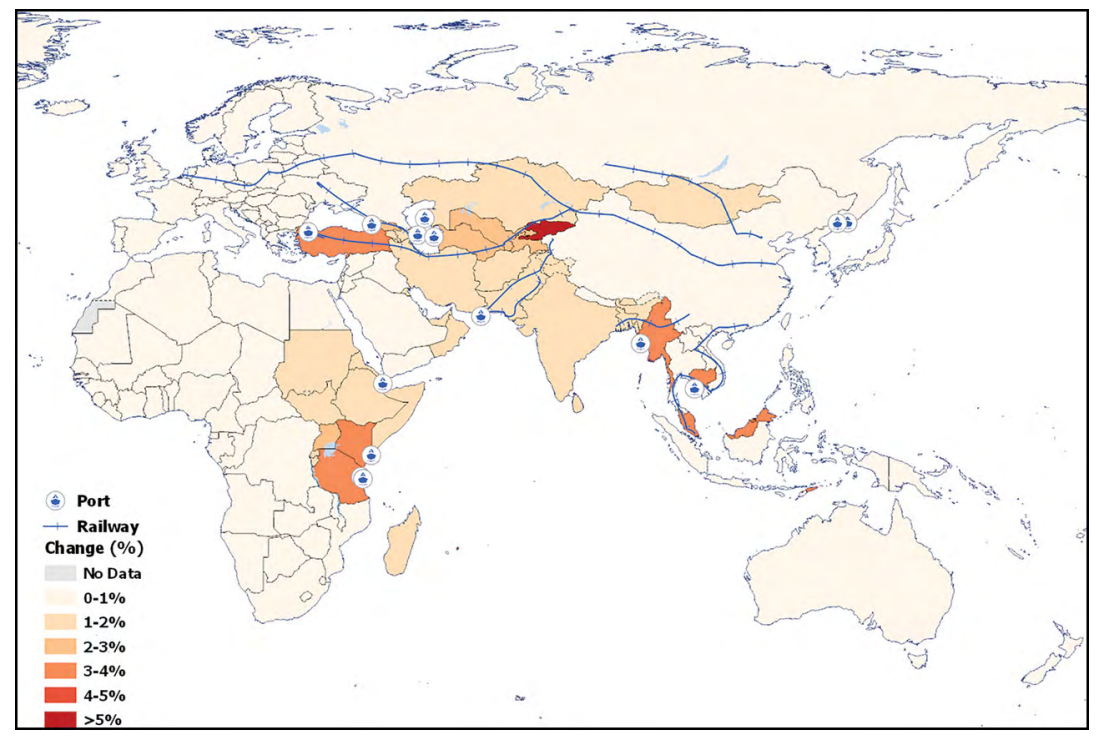

Figure 2.6 Average decline in trade costs by economy: Lower bound

Note: For each economy, all destinations are weighted by import flows.

Source: de Soyres et al. (2018).

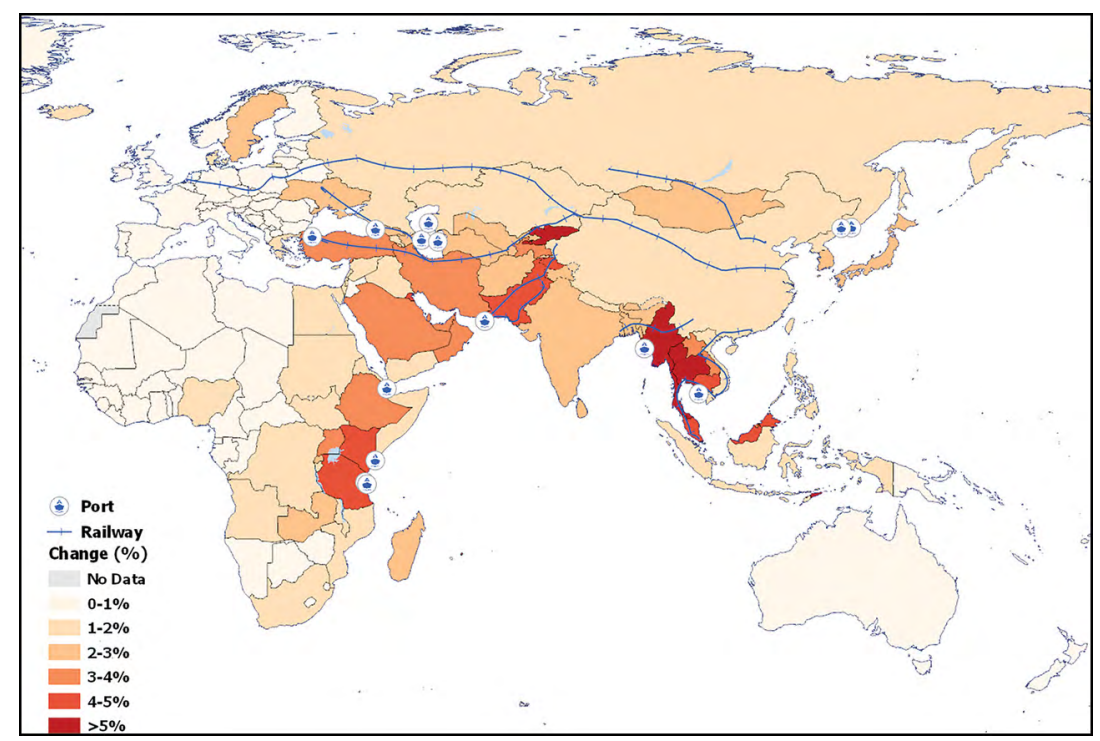

Figure 2.7 Average decline in trade costs by economy: Upper bound

Note: For each economy, all destinations are weighted by import flows.

Source: de Soyres et al. (2018). 


\section{Overall trade flows}

Based on the results for trade cost reductions from de Soyres et. al. (2018), Maliszewska and van der Mensbrugghe (2019) and de Soyres et al. (2019) use a dynamic computable general equilibrium (CGE) model and a static structural general equilibrium (SGE) model, respectively, to study the impacts of BRI infrastructure improvements on trade (see Figure 2.8).

According to the results from the CGE model, the exports of the BRI economies increase by 2.8 per cent (in 2030 relative to the baseline) and global exports increase by 1.7 per cent. The BRI countries that will experience the largest trade growth are Thailand (14.9 per cent), Malaysia (12.4 per cent), Pakistan (9.8 per cent) and Bangladesh (8.7 per cent). Non-BRI economies can also benefit from the denser transport network generated by BRI-related transport projects, experiencing an increase in export volume of 0.7 per cent in aggregate. Among the non-BRI economies, Ethiopia will obtain the largest trade gains by taking advantage of the new ports in East Africa, with an increase in exports of 3.9 per cent. The United States and the remaining high-income economies will also benefit greatly, with their export volumes increasing by 3.4 per cent and 1.4 per cent, respectively. ${ }^{6}$ However, not all non-BRI economies will benefit from the BRI's improved transportation network. The nonBRI economies in Latin America and the rest of Western Europe will experience a slight decrease in trade (by -0.5 per cent and -0.3 per cent, respectively) due to trade diversion. ${ }^{7}$

The trade effects of the BRI infrastructure improvements projected by the SGE model are similar to those predicted by the CGE model but tend to be much larger. The BRI economies are projected to increase exports by up to 9.7 per cent, while global export volumes will go up by 6.3 per cent. The proportional increase in the non-BRI economies' exports is predicted

5 The CGE model in Maliszewska and van der Mensbrugghe (2019) is the ENVISAGE model developed by the World Bank, incorporating five production factors, 28 sectors and 34 countries and regions. The SGE model in de Soyres et al. (2019) is based on the Ricardian model in Caliendo and Parro (2015), which includes sectoral linkages, trade in intermediate goods and sectoral heterogeneity, comprising 107 countries and regions. The CGE model has a more detailed structure of the economy than the SGE model, which comes at the expense of a higher level of aggregation of countries into large regions.

6 The remaining high-income economies include Australia, New Zealand, Hong Kong, Japan, South Korea, Taiwan and Canada.

7 The rest of Western Europe includes Austria, Belgium, Cyprus, Denmark, Finland, France, Germany, Greece, Ireland, Italy, Luxembourg, Malta, Netherlands, Portugal, Spain, Sweden, the United Kingdom, Switzerland and Norway. 
to be 4.1 per cent. The results from the two models are complementary and should be viewed as providing a range for the potential trade-promoting effects of the BRI transport infrastructure improvements. Unlike the CGE analysis, the SGE model stresses the connections through GVCs because it supposes that there are strong complementarities between the foreign and domestic inputs in production. As trade costs fall due to the denser transportation network, the SGE model projects that firms will increase their use of imported input products, with larger promotion effects on their productivity and export volumes.

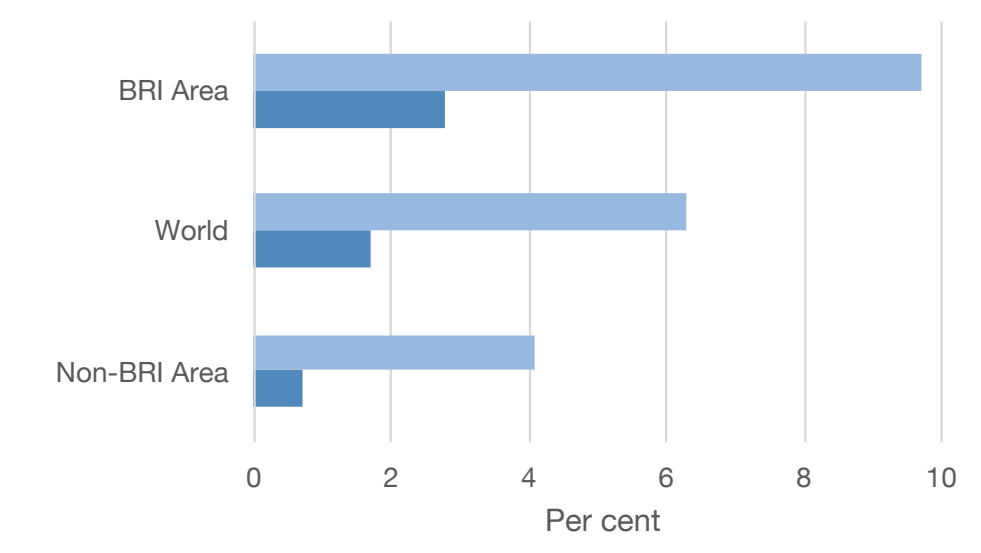

- Structural general equilibrium model $\square$ Computable general equilibrium model

\section{Figure 2.8 Export-promoting effects of BRI infrastructure} improvements: Upper bound

Sources: de Soyres et al. (2019); Maliszewska and van der Mensbrugghe (2019); World Bank (2019).

\section{Bilateral trade flows}

The BRI is anticipated to reshape trade relationships for participating economies with each other and with the rest of the world. Long trading times before the implementation of the BRI led to the downturn in intra-BRI country trade (see Table 2.1). The SGE model predicts that implementing all BRI-related transport projects will induce growth of 7.2 per cent in intra-BRI country trade.

Changes in trade flows will differ by region, depending on the extent to which new or improved infrastructure affects trade costs and the countries' economic structures. Table 2.2 reports that all BRI regions, except the Middle East and North Africa, will expand their exports to East Asia and the Pacific, reflecting a surge in imports for economies like China, 
Thailand and Malaysia. The BRI transport infrastructure improvements will also lead to an increase in exports from East Asian and Pacific economies to other BRI regions-most remarkably, to the Middle East and North Africa (10.98 per cent), Europe and Central Asia (8.63 per cent) — and among themselves (5.88 per cent). Regional value chains will be intensified. Other significant changes in bilateral trade flows are the increase in exports from the Middle East and North Africa to Europe and Central Asia (37.87 per cent) and South Asia (25.90 per cent). This can be interpreted by firms' access to cheaper inputs from other BRI regions, which enhances their competitiveness in overseas markets. Such channels are of particular importance for firms in Europe and Central Asia, whose exports to non-BRI areas will increase by 18.35 per cent.

Table 2.2 Changes in BRI regional trade flows

\begin{tabular}{|l|l|r|r|r|r|r|r|}
\hline & $\begin{array}{l}\text { From BRI } \\
\text { to BRI }\end{array}$ & $\begin{array}{c}\text { East } \\
\text { Asia } \\
\text { and } \\
\text { Pacific }\end{array}$ & $\begin{array}{c}\text { Europe } \\
\text { and } \\
\text { Central } \\
\text { Asia }\end{array}$ & $\begin{array}{c}\text { Middle } \\
\text { East } \\
\text { and } \\
\text { North } \\
\text { Africa }\end{array}$ & $\begin{array}{c}\text { South } \\
\text { Asia }\end{array}$ & $\begin{array}{c}\text { Sub- } \\
\text { Saharan } \\
\text { Africa }\end{array}$ & $\begin{array}{c}\text { Non- } \\
\text { BRI } \\
\text { area }\end{array}$ \\
\hline Exporters & $\begin{array}{l}\text { East Asia and } \\
\text { Pacific }\end{array}$ & 5.88 & 8.63 & 10.98 & 0.75 & -4.05 & 9.86 \\
\hline & $\begin{array}{l}\text { Europe and } \\
\text { Central Asia }\end{array}$ & 0.27 & 9.59 & 13.69 & 0.29 & 23.82 & 18.35 \\
\hline $\begin{array}{l}\text { Middle East and } \\
\text { North Africa }\end{array}$ & -1.76 & 37.87 & 3.76 & 25.90 & 8.21 & 8.59 \\
\cline { 2 - 8 } & South Asia & 5.98 & 13.86 & 8.52 & 1.12 & -1.45 & 5.65 \\
\hline & $\begin{array}{l}\text { Sub-Saharan } \\
\text { Africa }\end{array}$ & 16.95 & 22.37 & 11.00 & 17.43 & -0.28 & 15.03 \\
\hline
\end{tabular}

Source: de Soyres et al. (2019).

In terms of the trade effects of BRI digital connectivity, Zhang (2018) uses the gravity model to investigate the impact of telecommunications infrastructure construction on bilateral trade flows among the BRI countries in Asia, which shows that each 1 per cent increase in the level of telecommunications infrastructure will lead to a 1.56 per cent rise in import volumes. Compared with transport infrastructure, the improvement in telecommunications infrastructure can not only raise trade efficiency, but also reduce information asymmetry, which helps the price mechanism come into play. 


\section{Impact of BRI policy coordination on trade}

Policy coordination in the BRI framework plays a non-negligible role in achieving unimpeded trade. Based on the quadratic assignment procedure, Chong and Qin (2017) compare the trade networks before and after the implementation of the BRI and find that intergovernmental trade agreements have a significant and positive impact on trade in the BRI economies. Tao and Qiao (2020) achieved a similar result by using the gravity model. Tian and Liu (2019) examine the validity of the BRI and suggest it has boosted bilateral trade among the participating economies, helping avoid the trend of reverse globalisation. Zheng and Zhou (2019) further classify the BRI corridor economies into those that have reached intergovernmental trade agreements and those that have not, noting that trade agreements have a greater potential trade-promoting effect on the BRI economies without agreements. This can be explained by the fact that the BRI economies without trade agreements mostly adopt protectionist policies and set higher trade barriers for their relatively backward economies. Once a trade agreement is reached to lower trade barriers, it will create a lot of trade.

Policy coordination can magnify the trade gains from infrastructure improvements. De Soyres et al. (2019) simulate two scenarios of complementary policy reform for the BRI economies: 1) a 50 per cent decline in border delays, and 2) a 50 per cent decline in preferential tariffs. As shown in Figure 2.9a, a decrease in border delays and tariffs will amplify the promotion effects of BRI-related transport projects by a factor of about four on global trade, and even five on trade among the BRI economies. In terms of border delays, if, in addition to the transportation network improvements, border delays are reduced by half, exports from the BRI economies will increase by 28.1 per cent. This is not surprising given the long delays at the borders of many BRI economies. It can be verified in Figures 2.9b and 2.9c: the largest trade-promoting effect of BRI infrastructure improvements and border delay reductions will be for low-income economies and the Middle East and North Africa, which tend to have longer border delays. In terms of tariffs, a 50 per cent decline in tariffs among all the BRI economies will amplify the trade-promoting effect of BRI-related infrastructure projects more than the 50 per cent decline in border delays. Not surprisingly, regions with higher tariffs, such as sub-Saharan Africa, will obtain the largest trade gains under this policy scenario. 

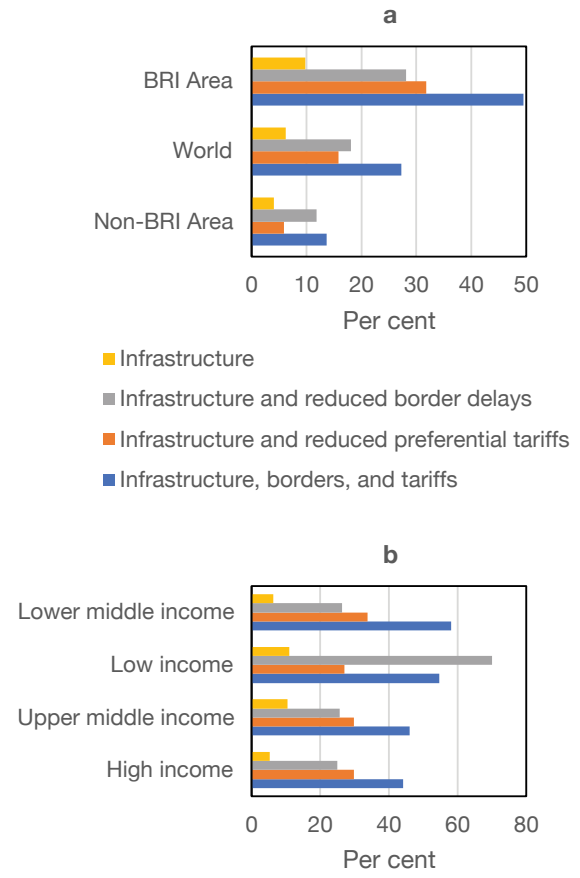

- Infrastructure

- Infrastructure and reduced border delays

- Infrastructure and reduced preferential tariffs

Infrastructure, borders, and tariffs

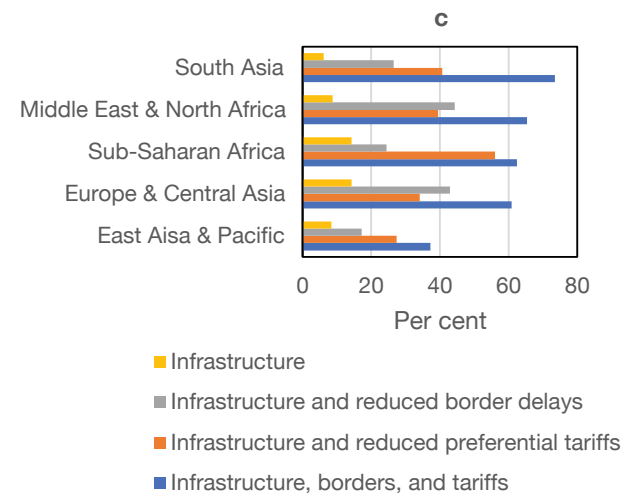

Figure 2.9 Trade-promoting effects of BRI infrastructure improvements and policy coordination
a) Gains by area
b) Gains by income group
c) Gains by region

Source: de Soyres et al. (2019). 


\section{Enhancement of trade facilitation}

Both infrastructure connectivity and policy coordination can promote trade through enhancing trade facilitation. Feng and Zhang (2019) identify a core of 23 countries along the six BRI corridors by sifting through the data in the Global Enabling Trade Report 2016, the Global Competitiveness Report 2019 and the World Bank's World Development Indicators (WEF 2016, 2019; World Bank 2021a). Based on this, they compute changes in the levels of trade facilitation in the six BRI corridors from 2013 to 2018. Their trade facilitation index is weighted by four firstlevel indicators-namely, 'government capacity and policy environment', 'customs and border management', 'logistics and infrastructure' and 'financial and communication capability'-which are subdivided into 11 second-level indicators and 27 third-level indicators.

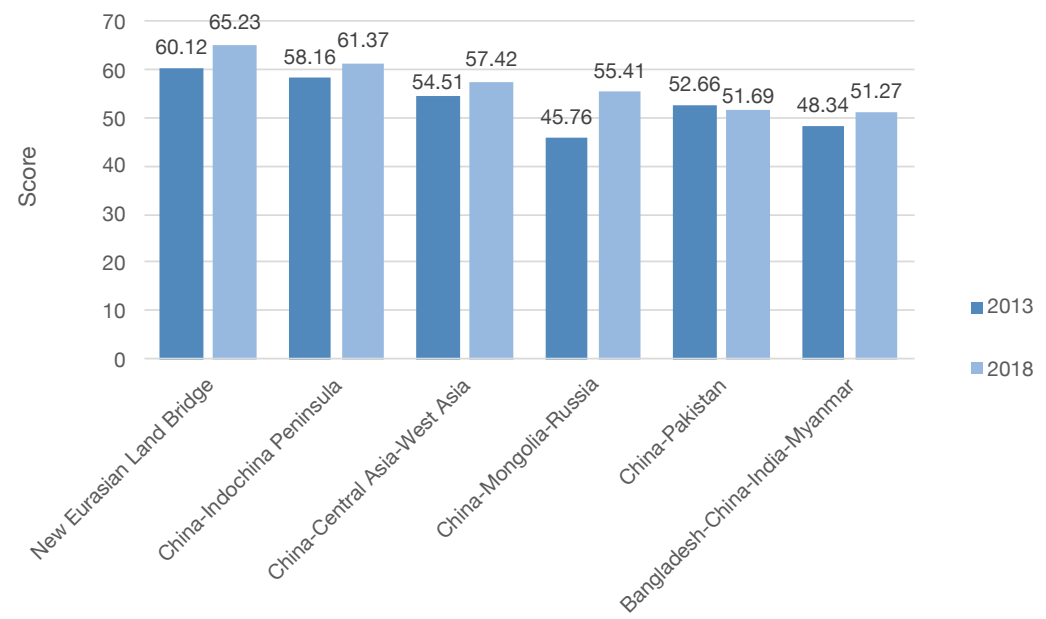

Figure 2.10 Trade facilitation scores for the BRI economic corridors, 2013 and 2018

Source: Feng and Zhang (2019).

Since 2013, with the exception of the China-Pakistan Economic Corridor, trade facilitation in the BRI economic corridors has improved significantly but the degree of development varies with each corridor (see Figure 2.10). Among them, the New Eurasian Land Bridge (65.23 points) had the best performance in 2018, while the Bangladesh-China-India-Myanmar Economic Corridor (51.27 points) had the worst, with its weakest areas in 'financial and communication capability' and 'logistics and infrastructure' (Feng and Zhang 2019). The China-Mongolia-Russia Economic 
Corridor has experienced the largest improvement in trade facilitation, particularly in 'financial and communication capability' and 'customs and border management' (Feng and Zhang 2019).

\section{Impact on the structure of trade networks}

The BRI has brought the trade network between the corridor economies closer and changed its structure from a multicore pattern to one with China as its single core. Zhao and Sun (2019) map the simplified BRI trade network for 2003 and 2017, which retains only the largest trade flows between the 66 BRI countries and regions (see Figures 2.11 and 2.12). Before the launch of the BRI, China had become one of the central nodes of the regional trade network, in 2003, directly connecting economies including Thailand, India, Vietnam, Saudi Arabia, Egypt, Israel and so on. Meanwhile, Russia was also a core node of this regional trade network, linking economies such as Turkey, Romania, Greece and the other members of the Commonwealth of Independent States. Hence, there was a multicore BRI trade network in 2003. However, some BRI economies remained independent from this network, such as Slovakia, Czech Republic, Slovenia, Croatia and North Macedonia, which indicates the network was relatively loose in 2003 .

The structure of the BRI trade network changed in 2017. China's central role has been significantly enhanced: more economies have direct trade linkages with China. There were many economies indirectly connecting with China through 'brokers' (like India, Thailand and Israel) in 2003, but in 2017, China became their largest trading partner. Zhao and Sun (2019) indicate the sustained development of China's economy and trade is the most important reason for this transformation. On the other hand, the density of the Commonwealth of Independent States' trade network, with Russia as its core, has decreased. The scope of the isolated local trade network has also declined: only the largest trade flows of Slovenia, Croatia and Bosnia and Herzegovina were not directly connected to the core BRI trade network in 2017. This reflects the fact the BRI has reduced the decentralisation of regional trade in the area and gradually deepened regional trade integration. 


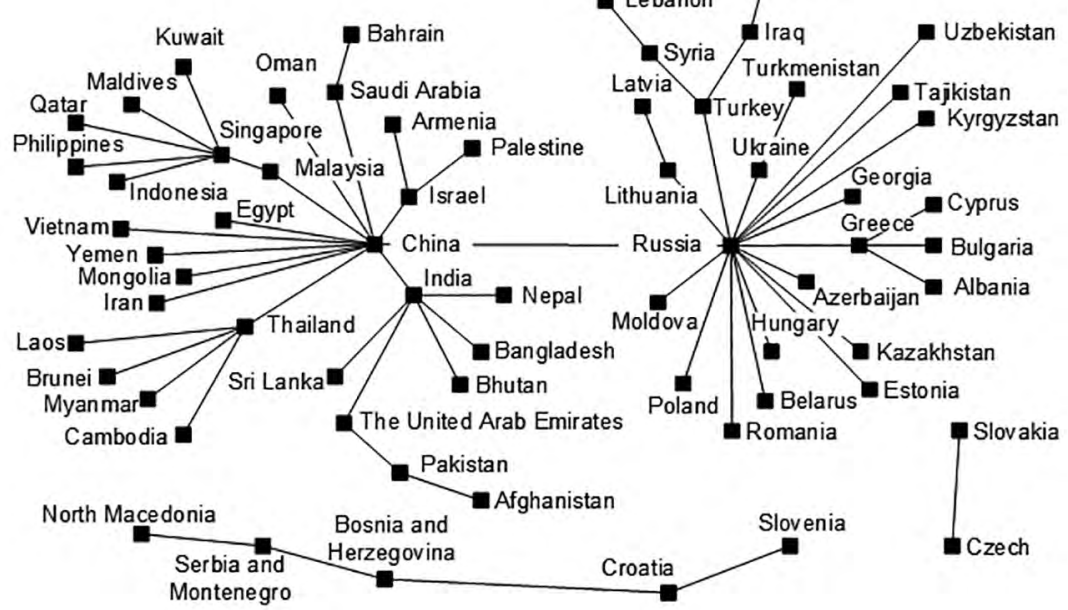

Figure 2.11 Structure of BRI corridor economies' trade networks, 2003 Source: Zhao and Sun (2019).

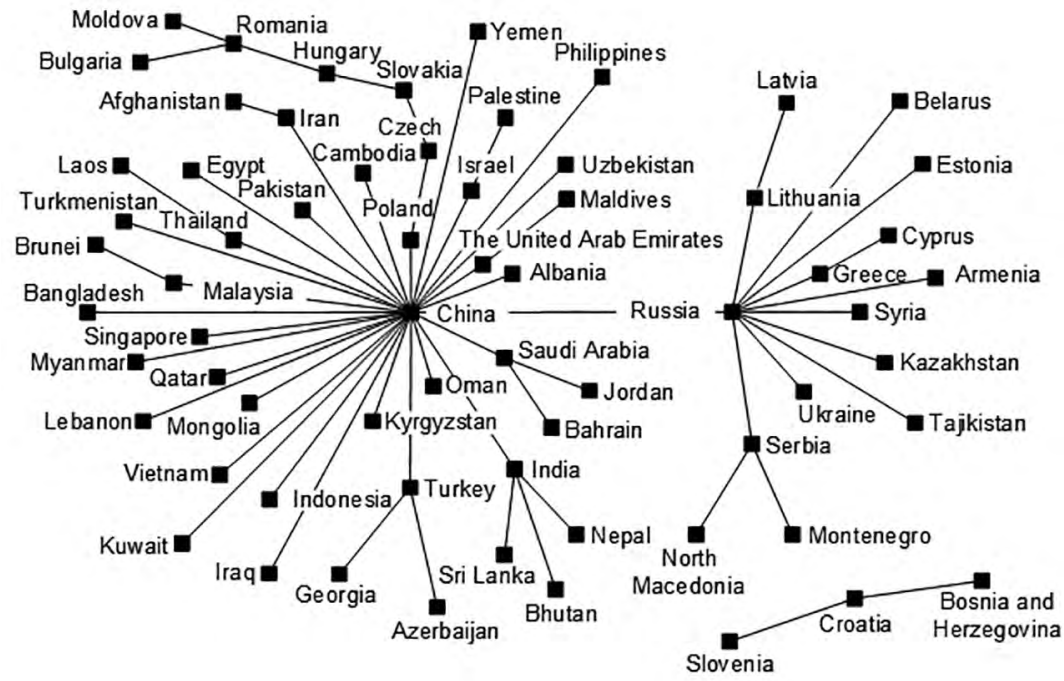

Figure 2.12 Structure of BRI corridor economies' trade networks, 2017 Source: Zhao and Sun (2019). 


\section{Impacts on foreign direct investment}

Longer travel time is a barrier to FDI flows. Based on the estimates in de Soyres et al. (2018), Chen and Lin (2018) studied the impact of the proposed BRI transportation network on FDI flows to the BRI economies. They find the proposed infrastructure improvements are projected to induce a 4.97 per cent increase in total FDI flows to the BRI economies. Specifically, there will be a 4.36 per cent increase in FDI flows within the BRI area, a 4.63 per cent increase in FDI flows from the Organisation for Economic Co-operation and Development (OECD) economies and a 5.75 per cent increase in FDI flows from the non-BRI area.

Across regions, the proposed BRI transportation network will lead to the largest increase in FDI flows to BRI economies in sub-Saharan Africa (7.5 per cent), followed by Central Asia (7.3 per cent), East Asia and the Pacific (6.3 per cent), South Asia (5.2 per cent), Europe (3.7 per cent) and the Middle East and North Africa (3.4 per cent) (see Figure 2.13).
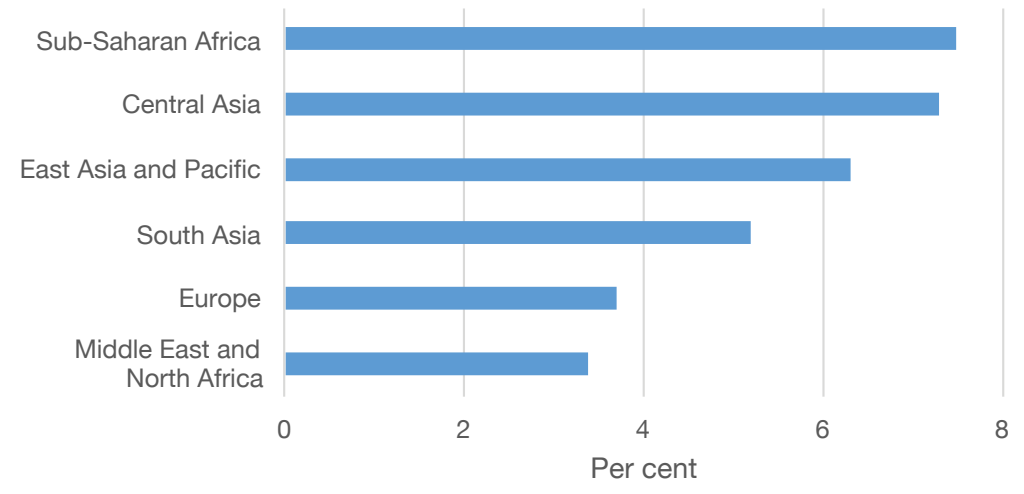

Figure 2.13 Promotion effects on FDI of BRI infrastructure improvements

Sources: Chen and Lin (2018); World Bank (2019).

\section{Impacts on global value chains}

Based on value added in trade, Dai and Song (2019) measure the changes in correlations among GVCs from 2010 to 2017, finding that there has been a significant overall trend of enhancement and considerable adjustment. They further explore whether the reconstruction of GVCs is related to China's BRI. Their results show the industrial relevance of the BRI area to GVCs has been significantly reinforced, while that in the non-BRI 
area has been significantly weakened. It is worth noting that the relevance between the BRI and non-BRI areas has also shown a strengthening trend. From these results, a preliminary judgement can be reached that the implementation of the BRI has promoted the reconstruction of GVCs to a certain extent.

In fact, the economies along the BRI economic corridor have comparative advantages such as cheap labour and abundant natural resources, which make them important destinations for a new round of international industrial gradient transfers and considerable partners with which China can carry out cooperation on production capacity. Therefore, there are two possible reasons for the aforementioned GVC change. On the one hand, with the rising prices of production factors in China, especially labour costs, multinational companies in developed economies will relocate more of their industries and production links to BRI economies. On the other hand, in the BRI framework, China has actively transferred its industries that have gradually lost their comparative advantages to other BRI economies, and even carried out cooperation in high-end industries such as environmental protection, thus promoting the integration of the BRI economies into GVCs. If the former factor dominates, the reconstruction of GVCs may not be caused by China's BRI. To figure out this problem, Dai and Song (2019) first measure the changes in the upstream dependence of the BRI economies on North America, Western Europe and China.

The results in Table 2.3 show that the BRI economies in most regions have intensified their upstream dependence on North America, Western Europe and China, which verifies that the BRI economies are indeed important destinations for a new round of international industrial transfers. However, it should be noted that the upstream dependence of the BRI economies on China has increased the most.

Table 2.3 Changes in upstream dependence of the BRI economies on North America, Western Europe and China, 2010-17 (per cent)

\begin{tabular}{|l|r|r|r|r|r|r|}
\hline & \multicolumn{1}{|c|}{$\begin{array}{c}\text { East } \\
\text { Asia }\end{array}$} & \multicolumn{1}{c|}{ ASEAN } & $\begin{array}{c}\text { Eastern } \\
\text { Europe }\end{array}$ & $\begin{array}{c}\text { South } \\
\text { Asia }\end{array}$ & $\begin{array}{c}\text { Central } \\
\text { Asia }\end{array}$ & Others \\
\hline North America & 0.25 & 0.47 & 0.61 & -0.27 & -0.19 & 0.46 \\
\hline Western Europe & 0.46 & 0.75 & 4.76 & -0.29 & -0.71 & 1.31 \\
\hline China & 1.26 & 1.49 & 0.92 & 0.45 & -0.12 & 1.35 \\
\hline
\end{tabular}

Source: Dai and Song (2019). 
Dai and Song (2019) also compute the changes in the downstream influence of North America, Western Europe and China on the BRI economies. As shown in Table 2.4, China's downstream influence on the BRI economies has increased more than that of North America. Compared with Western Europe, China also has a greater upward trend in its downstream influence on the BRI economies-except for those in Eastern Europe, because they have close relations with Western Europe. Therefore, in terms of both upstream dependence and downstream influence, it can be inferred that the implementation of China's BRI has significantly promoted the reconstruction of GVCs.

Table 2.4 Changes in the downstream influence of North America, Western Europe and China on the BRI economies, 2010-17 (per cent)

\begin{tabular}{|l|r|r|r|}
\hline & North America & Western Europe & China \\
\hline East Asia & 0.16 & 0.15 & 1.11 \\
\hline ASEAN & 0.19 & 0.12 & 0.88 \\
\hline Eastern Europe & 0.11 & 0.76 & 0.30 \\
\hline South Asia & -0.06 & -0.04 & 0.06 \\
\hline Central Asia & 0.00 & -0.01 & 0.00 \\
\hline Others & 0.45 & 0.73 & 1.47 \\
\hline
\end{tabular}

Source: Dai and Song (2019).

Based on data from 2004 to 2014, Peng and Li (2018) find that China's outward foreign direct investment (OFDI) in the BRI economies can improve its position in GVCs through the industrial separation effect. This is because, after transferring certain industries to the BRI economies, Chinese firms can make room for higher-tech production links or industries that retain comparative advantages. At the same time, China's OFDI in the BRI economies can improve the host country's position in GVCs through positive technology spillovers and demand-pull effects. In the case of industrial separation, on the one hand, Chinese firms may transfer some advanced technologies to the BRI economies to ensure the quality of imported intermediate products; on the other, when firms can spare more energy to improve product quality, consumer demands for products will increase, which will further strengthen the existing production mode and gradually improve the host country's position in GVCs. 


\section{Risks along the Belt and Road}

BRI-related projects involve various inherent risks, which are exacerbated by weak risk-prevention and control mechanisms and poor economic foundations in many participating economies. How to identify and manage these risks appropriately and efficiently becomes increasingly worthy of attention.

\section{Political and legal risks}

The complexity and impact of political and legal risks are difficult to assess. Political changes and differences in legal systems may lead to changes in the way foreign loans or direct investment are made and pose more challenges to the implementation of cross-border projects.

A political risk may be distinguished from others by defining it as one that causes losses due to certain political incidents, such as a change in national government or the deterioration of relationships between countries. Political risks can be categorised as geopolitical risks, risks of political power change, sovereign credit risks, as well as risks of nationalisation. Since most of the BRI economies are in geopolitically fragmented regions, and the development of the BRI entails the interests and strategic goals of some world powers, geopolitical risks become a major component of political risk. Most of the time, the risk of a change in political power will affect OFDI through evoking turbulence in society and increasing uncertainties about the executive effectiveness of contracts. Sovereign credit risks exist as the host countries or regions may default during the projects. According to the Handbook of Country Risk issued by the China Export \& Credit Insurance Corporation (Sinosure 2017, 2018), the overall sovereign credit level of the BRI economies is far below the world average. In addition, to protect domestic industries, the host government may issue policies to restrict the effective control of local assets by foreigninvested enterprises, which is actually an expropriation of those enterprises.

One typical case of political risk is the Myanmar Myitsone Hydropower Project initiated by the Myanmar Government with the China Power Investment Corporation in 2006. There have been many twists in the development of the project over the past decade or so, and it is still on hold. This is mainly due to the political conflicts between the central government and the Kachin Independence Army, the National League 
for Democracy and various Western nongovernmental organisations in Myanmar, which is in a geopolitically fragmented region and faces risks created by games among the great powers.

Legal risks comprise changes to or uncertainties in systems of foreign investment, intellectual property protection, labour rights protection, environmental regulation, taxation, foreign exchange management and so on. There are significant differences between the laws and regulations of the BRI economies and, in many, they are incomplete.

In 2012, the Aluminium Corporation of China Limited (Chinalco) announced its intention to make a bid for a proportional takeover of up to 60 per cent of the common shares of Ivanhoe Mines' subsidiary coalminer SouthGobi Resources, which eventually failed. To stop Chinalco's acquisition of SouthGobi Resources, the Mongolian Government hastily introduced new foreign investment supervision laws. Mongolia lacks a complete legal system and a stable legal environment for investment. Overall, the legal factors played an influential role in the failure of this acquisition.

According to Guo (2020), there are a number of options to reduce the risks mentioned above. The governments of BRI corridor economies could actively undertake political diplomacy with one another and sign more high-quality bilateral or regional trade and investment agreements so their economies can build and rely on multilateral, pluralistic and multilevel cooperation mechanisms to provide policy and institutional guarantees. More specifically, the BRI economies could establish a joint meeting mechanism for their leaders to coordinate and resolve issues associated with trade and investment cooperation and provide a normalised platform for healthy, orderly and sustainable development of cooperation.

\section{Debt sustainability risks}

As described in a report called Harmonizing Investment and Financing Standards Towards Sustainable Development Along the Belt and Road by the China Development Bank (CDB 2019), the debt sustainability of countries along the BRI economic corridor has become a focus regionally and has also drawn attention from the international community. It is necessary to balance the relationship between financing development needs and debt sustainability. 
Table 2.5 Sovereign credit risk ratings of the BRI countries and regions, 2017-18

\begin{tabular}{|c|c|c|c|c|c|c|c|}
\hline Region & Country & 2017 & 2018 & Region & Country & 2017 & 2018 \\
\hline \multirow{2}{*}{$\begin{array}{l}\text { Northeast } \\
\text { Asia }\end{array}$} & Russia & BB & BBB & \multirow[t]{7}{*}{ South Asia } & India & BBB & BBB \\
\hline & Mongolia & $\mathrm{CC}$ & $\mathrm{CCC}$ & & Pakistan & B & B \\
\hline \multirow{11}{*}{$\begin{array}{l}\text { Southeast } \\
\text { Asia }\end{array}$} & Singapore & A & AA & & Bangladesh & BB & BB \\
\hline & Malaysia & A & A & & Sri Lanka & CCC & CCC \\
\hline & Indonesia & BBB & BBB & & Maldives & CC & CC \\
\hline & Myanmar & B & B & & Bhutan & CCC & CCC \\
\hline & Thailand & BBB & BBB & & Nepal & CCC & $\mathrm{CCC}$ \\
\hline & Laos & $\mathrm{CcC}$ & CCC & \multirow[t]{5}{*}{ Central Asia } & Kazakhstan & BBB & BBB \\
\hline & Cambodia & B & B & & Uzbekistan & B & B \\
\hline & Vietnam & BB & BB & & Tajikistan & $\operatorname{CcC}$ & CCC \\
\hline & Brunei & BBB & BBB & & Turkmenistan & BBB & BBB \\
\hline & Philippines & BBB & BBB & & Kyrgyzstan & CC & CC \\
\hline & Timor-Leste & $\mathrm{CC}$ & $\mathrm{CC}$ & \multirow{19}{*}{$\begin{array}{l}\text { Central and } \\
\text { Eastern } \\
\text { Europe }\end{array}$} & Moldova & B & B \\
\hline \multirow{19}{*}{$\begin{array}{l}\text { West Asia } \\
\text { and North } \\
\text { Africa }\end{array}$} & Yemen & CCC & $\mathrm{CC}$ & & Belarus & BB & BB \\
\hline & Iraq & BB & BB & & Ukraine & CCC & $\mathrm{CCC}$ \\
\hline & Iran & BB & BB & & Albania & CCC & B \\
\hline & Israel & AA & AA & & Estonia & A & A \\
\hline & $\begin{array}{l}\text { United Arab } \\
\text { Emirates }\end{array}$ & $A$ & A & & Bulgaria & BB & BB \\
\hline & Oman & BB & BB & & \begin{tabular}{|l} 
Bosnia and \\
Herzegovina
\end{tabular} & $\operatorname{CcC}$ & CCC \\
\hline & Turkey & BBB & BB & & Poland & AA & AA \\
\hline & Syria & C & C & & Montenegro & $\operatorname{ccc}$ & B \\
\hline & Jordan & BB & BB & & \begin{tabular}{|l} 
Czech \\
Republic
\end{tabular} & AAA & AAA \\
\hline & Lebanon & BB & BB & & Croatia & BBB & BBB \\
\hline & Saudi Arabia & A & A & & Latvia & BBB & BBB \\
\hline & Qatar & A & A & & Lithuania & A & A \\
\hline & Kuwait & BBB & BBB & & Romania & BBB & BBB \\
\hline & Bahrain & BB & BB & & \begin{tabular}{|l} 
North \\
Macedonia \\
\end{tabular} & BB & BB \\
\hline & Egypt & $\operatorname{CCC}$ & CCC & & Hungary & A & A \\
\hline & Afghanistan & $\mathrm{CC}$ & $\mathrm{CC}$ & & Serbia & B & $\mathrm{B}$ \\
\hline & Azerbaijan & BB & BB & & Slovakia & AA & AA \\
\hline & Georgia & $\mathrm{B}$ & B & & Slovenia & A & A \\
\hline & Armenia & $\mathrm{CCC}$ & CCC & & & & \\
\hline
\end{tabular}

Sources: Sinosure $(2017,2018)$. 
Debt sustainability risks come from a country's present and future ability to fulfil its debt servicing obligations, which are affected by its current debt level and prospective borrowings. In general, a key factor for achieving external and public debt sustainability is macroeconomic stability. Large infrastructure investments involving debt financing in the BRI economies entail risks to debt sustainability. There is a need for systematic understanding, management and alleviation of debt sustainability risk by taking into account its historical and systematic causes from the perspective of national and global development. The level of sovereign credit risk is an indicator with which to analyse the sustainability of sovereign debt. Sinosure grades this risk into nine levels, from low to high: AAA, AA, A, $\mathrm{BBB}, \mathrm{BB}, \mathrm{B}, \mathrm{CCC}, \mathrm{CC}$ and $\mathrm{C}$. As shown in Table 2.5, the overall level of debt sustainability risk in the BRI economies is high, but shows a slight downward trend.

According to the World Bank (2019), in economies where there is low scrutiny or low risk of debt distress, if indebtedness is not substantially increased as a result of the BRI, they will generally have the fiscal space to increase investment. However, it is necessary that projects are selected and implemented well to maximise the gains and that financial terms are appropriate and transparent. In addition, evaluating the BRI's impact on the BRI economies' debt sustainability outlook and fiscal risks is also an important procedure. Economies with limited or no fiscal space for expansion would need to limit the number of debt-financed projects, rely on grants or highly concessional financing, favour FDI over debt financing and, if possible, increase public savings to finance additional investments.

When it comes to a concrete method for analysing debt sustainability risks, a framework is provided by China's Ministry of Finance. Specifying the scope of debt is the first step. China's framework clarifies the scope of debt as the general public sector debt on which the principal and/ or interest must be paid to creditors, including bonds, loans and other accounts payable. Dividing economies into groups and predicting their macroeconomic trends are critical methods to make the analysis clearer and more accurate. After these procedures, stress testing is performed on different scenarios to measure the sensitivity of the expected debt burden index to changes in given situations. Following the test, we could judge the risk signals, modify the model result and obtain a risk rating report. 
It is worth noting that accurate and timely information is the premise of reliable analysis. Governments should actively participate in the construction of the BRI risk-monitoring system and jointly build a comprehensive early warning system for project risk.

\section{Governance risks}

Governance risks vary across corridor economies and correlate closely with the quality of domestic institutions.

Large infrastructure projects can induce corruption-a common governance risk that is reflected in the abuse of public office for private gain. Infrastructure sector corruption can include improper influence over budgeting, the selection of projects and rent extraction in return for a carriage permit, construction contracts, leases or concessions (World Bank 2007). The World Bank indicates that corruption risks correlate closely with a country's development level, since lessdeveloped countries lack a strong rule of law and combating corruption is fundamentally about addressing poor governance. There is, indeed, a positive correlation between the Corruption Perception Index and the Rule of Law Index (see Figure 2.14). Countries or regions with high levels of corruption tend to have weak rule of law. This may be because the weak rule of law promotes and reduces the possibility of detecting corruption. According to the World Bank's Worldwide Governance Indicators database (2021b), the average score for corruption control in 64 major BRI economies was -0.26 in 2018 (ranging from -2.5 to 2.5) (see Figure 2.15). There were $40 \mathrm{BRI}$ economies (that is, more than half of the major BRI economies) with a Control of Corruption ranking in the bottom 50 per cent of the world. Consequently, the efficiency and transparency of BRI government work will be affected, which means FDI is likely to suffer corruption risks in the BRI economies.

Procurement in the BRI projects should be open, transparent and executed by the best-placed firms, regardless of their ownership or nationality, to avoid risk. For host borrowing economies, following international best practice is necessary to maximise value for money, which is also important for China and the financial institutions that finance BRI projects as it can help ensure the integrity and financial performance of projects. 


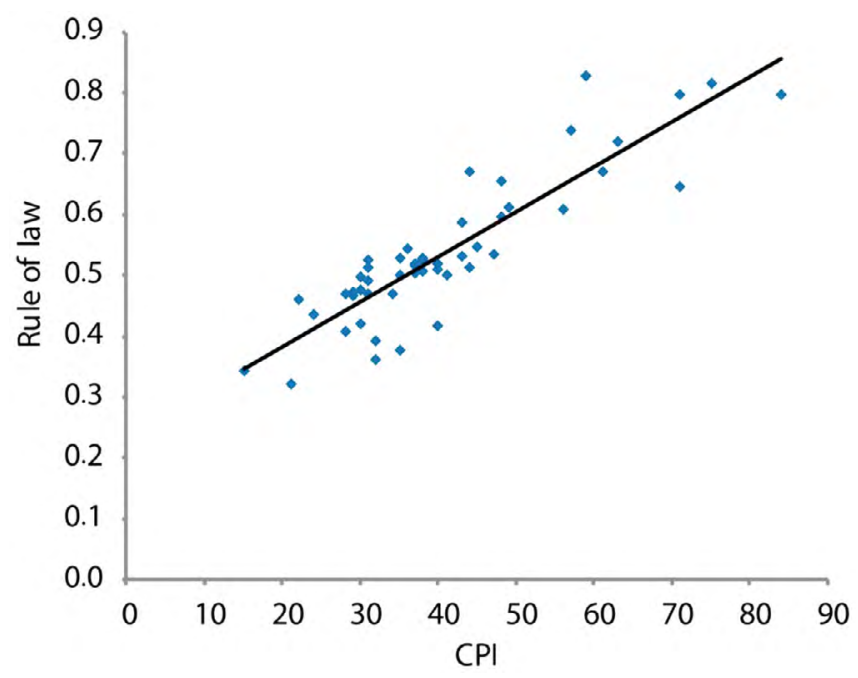

Figure 2.14 Relationship between Corruption Perception Index and Rule of Law Index for BRI economies, 2017

Note: Rule of Law Index scores range from 0 to 1, with 0 indicating weak perceived rule of law and 1 indicating strong perceived rule of law.

Source: World Bank (2019).

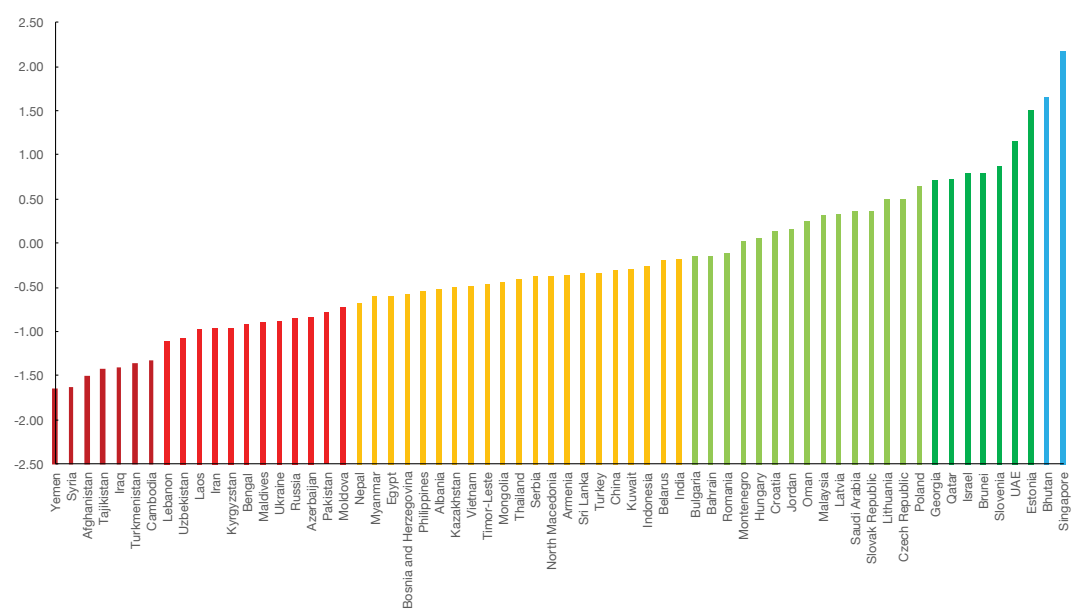

Figure 2.15 Control of Corruption scores for the BRI economies, 2018

Notes: The Control of Corruption scores range from -2.5 (weak control, high corruption) to 2.5 (strong control, low corruption). Blue bars indicate countries with governance scores in the top 10 per cent of 215 countries in the world; dark-green bars indicate countries in the top 10-25 per cent; light-green bars indicate countries in the top 25-50 per cent; orange bars indicate countries in the top 50-75 per cent; light-red bars indicate countries in the top 75-90 per cent; and dark-red bars indicate countries in the bottom 10 per cent.

Source: World Bank (2021a). 
Studies by the World Bank (2019) suggest that corruption mitigation can be divided into supply-side measures and demand-side measures. On the supply side, developing common auditing standards and enhancing audit and related institutions are critical. The multistakeholder Construction Sector Transparency Initiative can help economies obtain greater benefits from public infrastructure investment by improving transparency and accountability. Using a set of indicators called red flags that can alert officials to potential corruption during the infrastructure construction period is essential. Implementing integrity pacts and applying information and communications technology can also enhance transparency and reduce corruption risks. Social responsibility is the starting point for demand-side measures. Community monitoring and citizen report cards that strengthen public accountability can be implemented to effectively combat corruption and improve governance of projects.

Studies by the World Bank emphasise three tracks to improve procurement practices by the BRI host economies, China and multilateral international agreements. For the BRI hosts, a first step could be to use diagnostics related to the readiness of the national procurement system with pretendering due diligence before determining which procurement rules to apply. Mobilising resources to document the awarding of projects across economies could be an effective approach to increase transparency and generate more information. Two similar paths for China to enhance competition and transparency are associated with international best practice and establish a threshold for BRI projects. One is to introduce international competitive bidding and the other is to include foreigninvested enterprises and organise public national competition once the threshold is exceeded. In addition, multilateral cooperation, such as the WTO Government Procurement Agreement, can promote the use of transparent and competitive procurement practices.

\section{Environmental and social risks}

Many BRI projects are large-scale transportation projects that expose local communities to environmental and social risks.

Environmental risks refer to environmental pollution, natural resource destruction and other problems created during project construction that result in the risk of projects being shelved or huge fines for foreigninvested enterprises. Many BRI economies already have resource and environmental problems and, thus, numerous conservation areas have 
been constructed (see Figure 2.16). However, many still lack strong environmental supervision and protection systems (Guo 2020). In addition, environmental risks are also affected by political, economic and legal factors. For example, the host country may approve an engineering project for the sake of economic development, but it may also adopt strict environmental protection measures in the construction process under pressure from the public and domestic environmental nongovernmental organisations, or due to regime change or legal revision. Therefore, environmental risks need to be taken seriously.

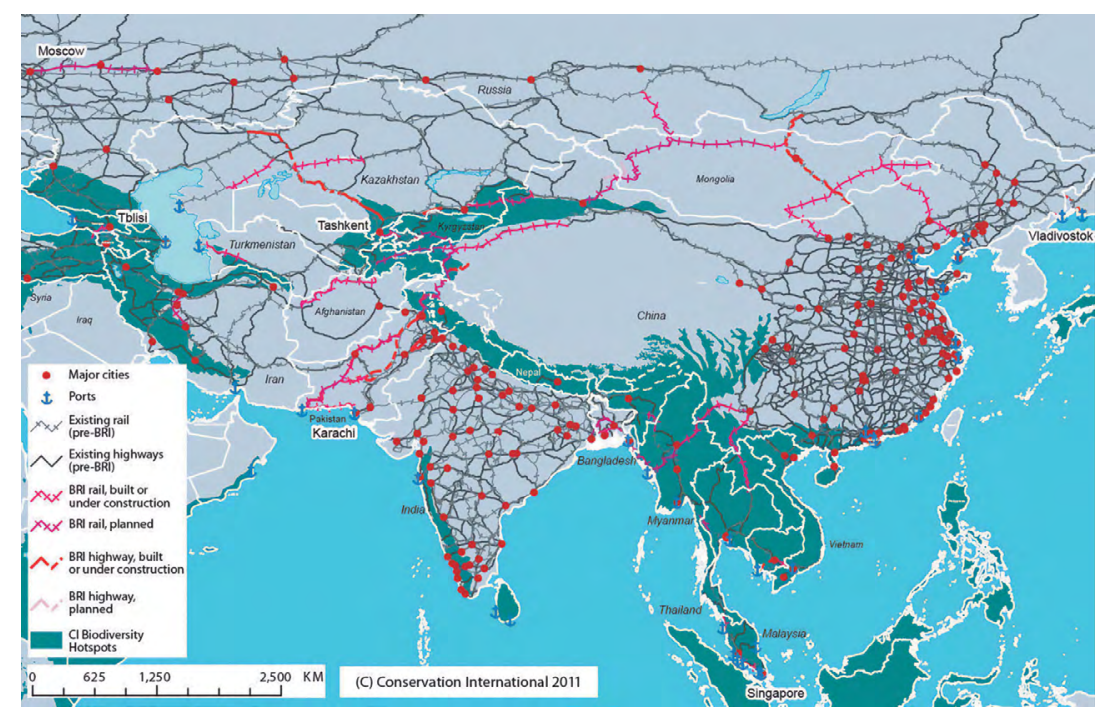

Figure 2.16 BRI road and railway projects in relation to biodiversity risks

$\mathrm{Cl}=$ Conservation International

Source: World Bank (2019).

According to Losos et al. (2018), the impacts of environmental risks include both the direct impacts of infrastructure construction and the indirect impacts caused by firms' response to new routes. Direct BRI environmental impacts include pollution from increased traffic, topographical and hydrological damage and the alteration of habitats at the expense of biodiversity. BRI projects tend to follow existing transport routes and substitute them with rail, which can reduce pollution compared with road and air travel. Indirect BRI environmental impacts could be both positive and negative. The positive impacts could include densification of settlement and production and a switch to off-farm activities that support rural land consolidation and restoration (Kaczan 2016). However, the 
negative effects are more pronounced, including increased emissions and opening up border locations to development. Environmental problems can develop by the creation not just of new settlements, but also of particularly high-cost activities such as logging and illegal wildlife trade.

Social risks are closely related to environmental risks, because communities and their environment are directly or indirectly affected by large-scale infrastructure projects. According to the World Bank (2019), the impacts that should be considered include:

- threats to human security

- disproportionate risks to vulnerable people

- discrimination against individuals or groups in the provision of development resources and project benefits

- involuntary requisition of land or restrictions on land use

- tenure and use of land and natural resources

- health, safety and wellbeing of workers and communities affected by projects

- cultural heritage.

In particular, the BRI projects pose a unique challenge of rapid migration to meet the need for labour. Rapid migration has negative impacts on local public infrastructure, utilities, housing, sustainable resource management and social dynamics (World Bank 2016a). More specifically, it leads to increased demand and competition for local goods and services, resulting in rising prices, the crowding out of local consumers and increased demand on resources, thus causing social conflict, increased rates of illegal activity and crime and even increased risks of the spread of infectious diseases.

There are four aspects to the policies to mitigate environmental risks that will be discussed in this section: avoid, reduce, restore and offset (World Bank 2019). Transport routes need to be arranged to avoid vulnerable environments- that is, to remove risks at the source. As a result, identification and analysis of alternative routes are essential. Integrating environmental consciousness into projects will reduce adverse impacts on the environment. Engineering and complementary policies include wildlife crossings, tunnel and bridge engineering, regulation and enforcement of forest and vulnerable species protection and social cost-benefit analyses in selecting transport options. Remedial measures for repairing damage created by the construction process are necessary 
to restore the environment. Meanwhile, offset can include investments in offsite locations to compensate for environmental damage that cannot be avoided, reduced or restored, so as to ensure neutral or positive environmental outcomes overall.

For social risks, the World Bank (2016a) has a framework for screening investments to identify the risk profile for labour influxes and determine the necessary mitigation measures_-such as encouraging the local recruitment of workers, affirmative action measures during the recruitment process to give women employment opportunities and ensuring that sufficient background checks are conducted on workers. Trafficking of women and children for prostitution as well as of drugs are issues that deserve attention. The spread of sexually transmitted diseases along traffic corridors should also be taken seriously by governments, which requires corresponding policies to limit their spread and raise people's awareness of prevention.

China has in fact made some efforts to reduce the environmental and social risks of the BRI. On 25 April 2019, 19 international financial institutions signed the 'Green Investment Principle of the Belt and Road Initiative' at the second BRF for International Cooperation. This principle aims to improve the BRI investment environment and social risk management level and promote green investment. It covers strategy formulation, corporate governance, project management, information disclosure and communication and the use of green financial tools.

\section{Conclusion}

China's BRI is a unique megaproject in global economic history, which is in line with President Xi Jinping's 'Thoughts' on China as a global power and on globalisation in the twenty-first century and contributes to fulfilling his mission of national rejuvenation. The project at its core incorporates elements of Chinese and Western philosophy, generates strategic flexibility and seeks relative economic advantage. The BRI is a key element of a new geopolitical mechanism that is seeking to protect China's national and security interests, incorporates historical experience (the Cold War) and could be seen as China's 'anti-containment' strategy because it contributes to the 'unification' of the Eurasian mainland (Heartland and Rimland) and seeks autonomy from the oceanic transportation network that is dominated by the United States. 
China's BRI has brought the connectivity between the BRI countries closer in terms of infrastructure and policy. As a result, it has shortened shipping times, lowered trade costs and injected strong impetus into the economies of the BRI countries, making the trade network between them more intensive, leading to greater FDI flows into them and improving their positions in GVCs.

The BRI projects involve various inherent risks, such as political and legal, debt sustainability, governance and environmental and social. Although Chinese companies have a wealth of experience, they may encounter many problems due to the wide range of BRI projects. With numerous opportunities for development presented by the BRI, these potential risks and the necessary countermeasures have become issues for attention.

\section{References}

BBC News. 2012. 'Full text: China's new party chief Xi Jinping's speech.' $B B C$ News, 15 November. Available from: www.bbc.com/news/world-asiachina-20338586.

Caliendo, L. and Parro, F. 2015. 'Estimates of the trade and welfare effects of NAFTA.' The Review of Economic Studies 82(1): 1-44.

Chen, M. and Lin, C. 2018. Foreign investment across the Belt and Road: Patterns, determinants, and effects. Policy Research Working Paper 8607. Washington, DC: World Bank Group. doi.org/10.1596/1813-9450-8607.

China Development Bank (CDB). 2019. Harmonizing Investment and Financing Standards Towards Sustainable Development Along the Belt and Road: Economic development along the Belt and Road. Beijing: CDB and United Nations Development Programme.

China Export \& Credit Insurance Corporation (Sinosure). 2017. The Handbook of Country Risk 2017. Beijing: China Financial Publishing House.

China Export \& Credit Insurance Corporation (Sinosure). 2018. The Handbook of Country Risk 2018. Beijing: China Financial Publishing House.

Chong, Z. and Qin, C. 2017. 'The trade network structure of "One Belt One Road" and its influence factors: A study based on analytic network process.' International Economics and Trade Research 33(5): 16-28. 
Communist Party of China (CPC). 2017. Constitution of the Communist Party of China: Revised and Adopted at the 19th National Congress of the Communist Party of China on October 24, 2017. Available from: www.xinhuanet.com/ english/download/constitution_of_the_communist_party_of_china.pdf.

Costas, G. 2019. 'The visit of President Xi Jinping: The "Silk Road” and Greece.' [In Greek], SL Press, 11 November. Available from: slpress.gr/ethnika/hepiskepsi-toy-proedroy-si-tzinpingk-o-quot-dromos-toy-metaxioy-quot-kaii-ellada.

Dai, X. and Song, J. 2019. 'Will “One Belt One Road” help China restructure GVC?’ World Economy Studies 11: 108-21, 136.

de Soyres, F., Mulabdic, A. and Ruta, M. 2019. Common transport infrastructure: A quantitative model and estimates from the Belt and Road Initiative. Policy Research Working Paper WPS8801. Washington, DC: World Bank Group. doi.org/10.1596/1813-9450-8801.

de Soyres, F., Mulabdic, A., Murray, S., Rocha, N. and Ruta, M. 2018. How much will the Belt and Road Initiative reduce trade costs? Policy Research Working Paper WPS8614. Washington, DC: World Bank Group. doi.org/10.1596/ 1813-9450-8614.

Dollar, D. 2020. 'Order from chaos: Seven years into China's Belt and Road.' Brookings Blog, 1 October. Washington, DC: Brookings Institution. Available from: www.brookings.edu/blog/order-from-chaos/2020/10/01/seven-yearsinto-chinas-belt-and-road.

Feng, Y. and Zhang, Q. 2019. 'Evaluation report on trade facilitation of the six economic corridors under the Belt and Road Initiative.' Frontiers 19: 64-91.

Guo, Z. 2020. Risks and Prevention \& Control Mechanisms of Chinese Enterprises' OFDI: A perspective of the 'Belt and Road'. Beijing: China Centre for International Economic Exchanges.

Hummels, D. and Schaur, G. 2013. 'Time as a trade barrier.' American Economic Review 103(7): 2935-59. doi.org/10.1257/aer.103.7.2935.

Jones, B. (interviewer). 2019. China's Belt and Road: The new geopolitics of global infrastructure development. A Brookings Interview. April. Washington, DC: Brookings Institution. Available from: www.brookings.edu/wp-content/ uploads/2019/04/FP_20190419_bri_interview.pdf.

Kaczan, D.J. 2016. Can roads contribute to forest transitions? PhD Thesis, Sanford School of Public Policy and Nicholas School of the Environment, Duke University, Durham, NC. 
Karpathiotaki, P. 2016. One Belt, One Road: The new type of globalization. $\mathrm{PhD}$ thesis, University of International Business and Economics, Beijing.

Li, X., Fan, Y. and Wu, L. 2017. ' $\mathrm{CO}_{2}$ emissions and expansion of railway, road, airline and inland waterway networks over the 1985-2013 period in China: A time series analysis.' Transportation Research Part D: Transport and Environment 57: 130-40. doi.org/10.1016/j.trd.2017.09.008.

Losos, E., Pfaff, A., Olander, L., Mason, S. and Morgan, S. 2018. Reducing environmental risks from Belt and Road Initiative investments in transportation infrastructure. Policy Research Working Paper 8718. Washington, DC: World Bank Group. doi.org/10.1596/1813-9450-8718.

Luo, Y., Xue, Q. and Han, B. 2010. 'How emerging market governments promote outward FDI: Experience from China.' Journal of World Business 45(1): 68-79. doi.org/10.1016/j.jwb.2009.04.003.

Maliszewska, M. and van der Mensbrugghe, D. 2019. The Belt and Road Initiative: Macro and sectoral impacts. Policy Research Working Paper WPS8814. Washington, DC: World Bank Group.

Ministry of Finance of the People's Republic of China (MOF). 2019. Debt Sustainability Framework for Participating Countries of the Belt and Road Initiative. Beijing: MOF.

Peng, P. and Li, J. 2018. 'OFDI and bilateral moving up in the global value chain: An empirical study on the Belt and Road Initiative.' Industrial Economics Research 6: 75-88.

Reed, T. and Trubetskoy, A. 2019. Assessing the value of market access from Belt and Road projects. Policy Research Working Paper WPS8815. Washington, DC: World Bank Group. doi.org/10.1596/1813-9450-8815.

Silk Road Guoxin Big Data Technology Co. Ltd. n.d. Belt and Road Portal. Beijing. Available from: www.yidaiyilu.gov.cn/xwzx/gnxw/102792.htm.

Tao, Z. and Qiao, S. 2020. 'Research on the influencing factors of the "Belt and Road" international trade: An empirical test based on trade agreements and logistics performance.' Journal of Social Sciences 1: 63-71.

Tian, J. and Liu, X. 2019. 'Validity test of regional trade agreements in the context of "reverse globalization": A case study of the Belt and Road Initiative.' Macroeconomics 7: 71-83.

United Nations (UN). 1974. Charter of Economic Rights and Duties. Article 26, GA Res. 3281(xxix), UN GAOR, 29th Sess., Supp. No. 31 (1974) 50. New York: UN General Assembly. 
Witt, M.A. and Lewin, A.Y. 2007. 'Outward foreign direct investment as escape response to home country institutional constraints.' Journal of International Business Studies 38(4): 579-94. doi.org/10.1057/palgrave.jibs.8400285.

Woetzel, J., Garemo, N., Mischke, J., Kamra, P. and Palter, R. 2017. Bridging infrastructure gaps: Has the world made progress? McKinsey Global Institute Executive Briefing. New York: McKinsey \& Company. Available from: www.mckinsey.com/business-functions/operations/our-insights/bridginginfrastructure-gaps-has-the-world-made-progress.

World Bank. 2007. The Many Faces of Corruption: Tracking vulnerabilities at sector level. Washington, DC: World Bank Group.

World Bank. 2016a. Managing the risks of adverse impacts on communities from temporary project induced labour influx. Guidance Note. Washington, DC: World Bank Group.

World Bank. 2016b. World Development Report 2016: Digital dividends. Washington, DC: World Bank Group.

World Bank. 2019. Belt and Road Economics: Opportunities and risks of transport corridors. Washington, DC: World Bank Group.

World Bank. 2021a. World Development Indicators. DataBank. Washington, DC: World Bank Group.

World Bank. 2021b. Worldwide Governance Indicators. DataBank. Washington, DC: World Bank Group.

World Economic Forum (WEF). 2016. The Global Enabling Trade Report 2016. Geneva: World Economic Forum.

World Economic Forum (WEF). 2019. The Global Competitiveness Report 2019. Geneva: World Economic Forum.

World Justice Project. 2018. Our Work. Washington, DC, and Seattle: World Justice Project.

Wu, Z. 2018. 'Functional logic of the Belt and Road Initiative: A new interpretation based on geo-economics.' World Economics and Politics 9: 128-53, 160.

Xie, T. 2015. 'Is China's "Belt and Road" a strategy? When is a strategy not a strategy?' The Diplomat, 16 December. Available from: thediplomat. com/2015/12/is-chinas-belt-and-road-a-strategy.

Xinhuanet. 2017. 'Full text of President Xi's speech at opening of Belt and Road forum.' Xinhuanet, 14 May. Available from: news.xinhuanet.com/english/201705/14/c_136282982.htm. 
Yang, J. (chair). 2019. Belt and Road Cooperation: For A Better World-Report on the findings and recommendations from the first meeting of the Advisory Council of the Belt and Road Forum for International Cooperation. 10 April. Geneva: Permanent Mission of the People's Republic of China to the United Nations Office at Geneva and Other International Organizations in Switzerland. Available from: www.china-un.ch/eng/zywjyjh/t1675576.htm.

Zhang, P. 2018. 'The infrastructure construction level of the Belt and Road impacts on bilateral trade from Asian countries: Analysis based on extended gravity model.' World Economy Studies 6: 70-82, 136.

Zhao, J. and Sun, H. 2019. 'Research on the evolution of trade relations between China and the countries along the Belt and Road.' International Economics and Trade Research 35(11): 36-48.

Zheng, J. and Zhou, S. 2019. 'Trade promotion effect of trade agreements between the countries along "the Belt and Road": An empirical analysis based on the propensity score matching model.' Economic Survey 36(6): 62-69. 
This text is taken from New Dimensions of Connectivity in the Asia-Pacific, edited by Christopher Findlay and Somkiat Tangkitvanich, published 2021 by ANU Press, The Australian National University, Canberra, Australia.

doi.org/10.22459/NDCAP.2021.02 